\title{
The Effect of Probiotics as a Starter Culture for Producing Yogurt
}

\section{SungHoo Jegal ${ }^{1}$, Helen Heacock ${ }^{2}$, Aljosa Trmcic ${ }^{3}$, Fred Shaw ${ }^{4}$}

1 Lead Author, School of Health Science, British Columbia Institute of Technology, Burnaby, BC 2 Supervisor, School of Health Science, British Columbia Institute of Technology, Burnaby, BC 3 Supervisor, BC Centre for Disease Control, Vancouver, BC 4 Contributor, School of Health Science, British Columbia Institute of Technology, Burnaby, BC

\section{Abstract}

Background: Many comprising studies showed that probiotics can manifest antimicrobial activity. Due to positive health effects of probiotics, they have been added in a fermentation of various foods to increase the nutrient content and to improve the quality of the foods. Furthermore, probiotics are used as a starter culture for several fermented foods like a yogurt. Probiotics may contain strains that are capable of initiating fermentation of the foods, however, a safety of the foods is not certain. Therefore, the study is done to analyze use of probiotics as a starter culture for a yogurt.

Methods: The study was designed to analyze the $\mathrm{pH}$ pattern of three different yogurt groups (control, commercial starter culture, and probiotics). Each group had three samples that were made using Dairyland $2 \%$ milk and corresponding cultures. The control group samples were not inoculated with any culture. The commercial starter culture group samples were inoculated with Yogourtmet FreezeDried Starter and the probiotics group samples were inoculated with probiotic capsule, Jamieson 10 Billion Probiotic. The samples were incubated for 7 hours and every 45 minutes the $\mathrm{pH}$ was measured using Hanna Professional Portable Yogurt pH Meter.

Results: The statistical analysis of the $\mathrm{pH}$ measurement showed significant different between the control groups and other two groups. The control group samples $\mathrm{pH}$ decreased a bit, but it was not enough to turn the samples to a yogurt. 
The $\mathrm{pH}$ pattern of the commercial group samples showed rapid decrease in $\mathrm{pH}$ after 180 minutes and the average $\mathrm{pH}$ of the last reading was 4.10 . The $\mathrm{pH}$ of the probiotics group samples decreased linearly, and the average $\mathrm{pH}$ of the last reading was 4.58 .

Conclusions: The commercial starter culture and the probiotics group samples initiated fermentation and enough acidification occurred to decrease the $\mathrm{pH}$ below 4.6. With 7 hours of incubation period, the probiotics group samples just met the $\mathrm{pH}$ that makes the yogurt safe to consume. Therefore, the use of the probiotics as a starter culture for producing yogurt can be suggested with adequate incubation period.

Keywords: Yogurt, pH, probiotics, starter culture, fermentation, acidification

\section{Introduction}

Around the world, fermented foods are consumed, and there are various kinds of fermented foods such as yogurt, kefir, kombucha, sauerkraut, kimchi, miso, and cheese. These foods are prepared in various ways, and most of them are traditional foods that many people enjoy. The fermented foods, including fermented beverages, have probiotics that are known to be beneficial to humans when consumed. Because of growing demands for probiotics, many kinds of probiotic supplements are available in pill and capsule form. Many homemade and commercially produced fermented foods use probiotics as a starter culture to boost the speed of the fermentation, enrich the nutrient contents, and to control the quality of the foods. There has been much research done on probiotics and their clinical effects on humans but not much done on the safety of fermented foods in respect to $\mathrm{pH}$. The study will focus on the administration of probiotics and relative $\mathrm{pH}$ level of yogurt.

\section{Literature/Evidence Review}

History of Fermentation

Fermentation of food has a long history, and the means of fermentation was the preservation of foods in the past. Fermentation does not only apply for foods, but it is also incorporated with 
alcoholic beverages. The earliest report of fermentation began in the Neolithic Chinese and ancient Roman era between $7000 \mathrm{BC}$ and $6000 \mathrm{BC}$. Many of the countries started to produce fermenting beverages and foods in the early period.

Especially in Asian culture, people developed a series of fermented foods and beverages for an everyday meal (Barbosa-canovas, 2016). Wine is popular alcoholic beverages produced by the fermentation process of fruit, honey, and rice; it has been conducted since 7000 BC (Chambers and Pretorius, 2010). Furthermore, the traditional fermented foods and beverages were frequently consumed for therapeutic purposes even though people did not have scientific evidence that describes the mechanism of the probiotics in the body (Ozen and Dinleyici, 2015).

\section{Fermented Food Safety}

Fermentation practices were carried out throughout the world. It has been such a long time since the development and production of indigenous fermented products. There are now a tremendous number of different types of fermentation foods around the world (Franz et al., 2014). In the past, the major purpose of fermentation was mostly related to preservation and people did not understand the mechanisms of fermentation. However, development in technology revealed health effects of fermented foods. Studies were done on foods to identify microorganisms that are responsible for fermentation and beneficial health effects (LourenesHasttingh and Viljoen, 2001). Development of technologies and growth of interest in fermentation foods lead to a new way of fermentation techniques (McNeil and Harvey, 2008). Many factors may affect the safety of the foods. Water activity, $\mathrm{pH}$, preservatives, temperature, and competitive microflora contribute to the fermentation, and a combination of these factors make the food safe to consume (Mclntrye, 2016). In the case of fermented foods, $\mathrm{pH}$ is the critical factor in determining the safety of the foods. $\mathrm{pH}$ of the fermented foods decreases due to the microbial activities (Russell and Diez-Gonzalez, 2008). There are no specific legislations or regulations regarding production of 
fermented foods. However, Mclntrye, food safety specialist from BCCDC created Fermented Food Safety advisory document. According to the document, the fermentation should occur within 24-72 hours and should reach a pH of 4.6 within 72 hours; $\mathrm{pH}$ of final products should not pass below 3.2. The water activity should be 0.85 or less and must be stored at temperature of 4 degree Celsius or less. Due to the fact that fermentation occurs spontaneously and requires bacterial growth, it is vital to reduce or eliminate pathogenic microorganisms that can be present in the raw source of the fermentation. Therefore, preparation and process of the fermentation must be conducted in a way that it will minimize cross contamination and avoid undesired microorganism in the foods or beverages.

\section{History of Probiotics}

Russian bacteriologist Eli Metchnikoff discovered the health effect of the probiotic in 1908. He found scientific evidence of the beneficial health effect of lactic acid bacteria in fermented milk and recommended people to drink fermented milk in order to prolong life (Lourens-Hattingh and Viljoen, 2001). Meanwhile, in 1899 , Henri Tissier isolated bifidobacteria from the feces of breast-fed infants by displacing the microorganisms responsible for gastric upsets (LourensHattingh and Viljoen, 2001; Lee and O'Sullivan, 2010).

\section{Probiotics}

The amount of microbiota in the gastrointestinal $(\mathrm{Gl})$ tract differs between individuals but approximately 10 - 100 trillion symbiotic microbiota has existed in the human gut (Ursell et al., 2012). Some of the microorganisms are pathogenic, and some are commensal; some of the commensal microorganisms are the same strains as the probiotics and have the same beneficial properties (Martin et al., 2013). The term probiotic refers to a viable bacterial microorganism which can have beneficial effects on humans (Kechagia et al., 2013). Theses friendly microorganisms are usually incorporated in the fermented foods. Due to the health effects of probiotics, demand for probiotics has increased drastically during the past two decades (Mattila-Sandholm et al., 2001). To 
satisfy the growing demand for

probiotics, industries have been working

on isolating and mass-producing

specific strains of probiotics (Fijan,

2014). The effects of the probiotics on

human are well studied. However, the

mechanisms, how they react with

certain organisms still needs to be

studied.

\section{Clinical Effect of the Probiotics}

Most of probiotics are consumed

orally and go through the human

digestive system. Once probiotics are in the body, they must be able to survive in the extremely low $\mathrm{pH}$ condition of a stomach and make their way to rest of GI tract. Therefore, in order to have a beneficial effect, probiotics must express certain desirable properties. The probiotics must be stable and viable in the digestive system which means that they are acid and bile tolerant, adhesive to mucosal and epithelial surfaces, and able to compete with pathogenic bacteria (Kechagia, 2013). Currently, many promising studies claim a significant scientific evidence of the beneficial effect of probiotics. Many people know that probiotics are good for the digestive system, but their potentials for clinical use are far beyond just digestive aids. The microbial balance and immune system in humans can be improved by consuming adequate amounts of probiotics. More specifically, they can be used to prevent and treat Helicobacter pylori infection, prevent systemic infections, manage inflammatory bowel diseases, prevent and treat atopic diseases, prevent and manage allergic diseases, and postoperative infections (Kelesidis and Pothoulakis, 2012; Gill and Guarner, 2004). Also, they have functions of anticarcinogenic and antimutagenic activities, mitigation of lactose intolerance symptoms, reduction in cholesterol and blood pressure level, prevention of bacterial vaginosis and urinary tract infection, retainment of mucosal integrity, and improvement of periodontal health (Franz et al., 2014). Sometimes they are used as a starter culture of the fermentation.

\section{Association of Food-borne Diseases} and Fermented Products

Although fermented products are considered as safe from foodborne diseases, outbreaks caused by fermented products are reported 
sometimes, and most of the outbreaks are due to mishandling of the initial and final products, or from improper processing of the fermentation. For example, according to Matargas et al. (2015), Salmonella enterica and Listeria monocytogenes are the pathogens that can be found in the raw materials of Italian fermented sausages cacciatore and Felino. If initially, the raw materials such as pork and chicken contain a large amount $\mathrm{S}$. enterica or $\mathrm{L}$. monocytogenes, the final sausage products are likely to contain unacceptable levels of the pathogens that are a health hazard to humans. However, if $\mathrm{pH}$ of the sausage decreased fast enough to a certain level and maintained at that $\mathrm{pH}$, then it will inactive the pathogens (Matargas et al., 2015).

\section{Methods and Materials}

\section{Materials}

The equipment required was a stainless saucepan, a Taylor instant read dial thermometer, a spatula, a whisk, $500 \mathrm{ml}$ glass beakers, glass shots $(50 \mathrm{ml})$, and an oven (Christensen, 2018). Dairyland pasteurized $2 \%$ inorganic milk was selected to make yogurt with two different starter cultures and one without starter culture. The commercial yogurt starter culture, Yogourtmet Freeze-Dried Starter, and probiotic capsule, Jamieson 10 Billion Probiotic, were used as a starter culture.

A

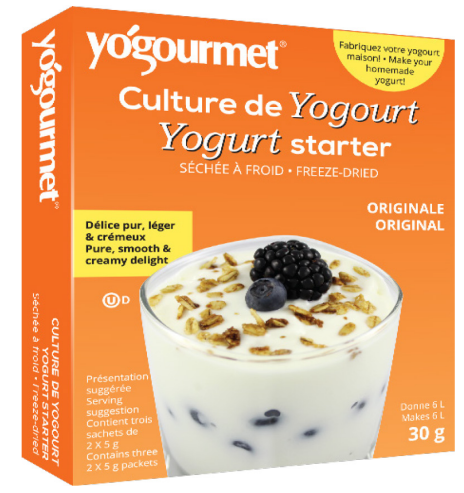

B

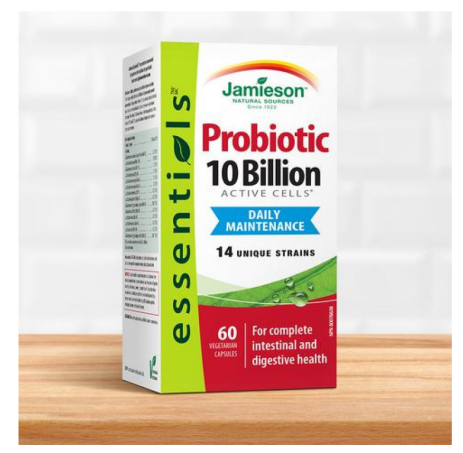

Fig. 1. Selected starter cultures for the experiment (A) Yogourtmet Commercial Starter Culture (Yogourtmet, n.d.). (B) Jamieson Probiotic Capsules (Jamieson, n.d.).

Ingredient of Starter Cultures The ingredients of Yogourtmet are skim milk powder, sucrose, 
Lactobacillus bulgaricus, Streptococcus thermophilus, and Lactobacillus acidophilus. It contains 100 billion live and active bacteria per $100 \mathrm{~g}$ serving (Yogourtmet, n.d.).

Jamieson 10 Billion Probiotic contain 14 strains of probiotics: Bifidobacterium lactis, Lactobacillus paracasei, Bifidobacterium breve, Lactobacillus gasseri, Lactobacillus rhamnosus, Lactobacillus rhamnosus, Lactobacillus acidophilus, Lactobacillus plantarum, Bifidobacterium longum, Bifidobacterium bifidum, Lactobacillus casei, Lactobacillus reuteri, Lactococcus lactis, and Bifidobacterium infantis. It contains 10 billion CFU of probiotics (Jamieson, n.d.).

\section{Preparation of Yogurt}

The experiments designed to repeated three times to increase the consistency and reliability of the results. As seen in the Fig. 2, there were 3 different groups, and each group consisted of 3 samples, therefore 9 samples were prepared for each experiment and in total 27 samples were prepared for the 3 experiments. The first group was the control. The control group samples were not inoculated with a starter culture and set for spontaneous fermentation. The second group samples were inoculated with the commercial starter culture (Yogourtmet). The third group samples were inoculated with the probiotics (Jamieson). Before making yogurt, all the equipment used for making yogurts were sterilized with boiling water to produce the accurate results. $1 \mathrm{~L}$ of $2 \%$ milk was poured into the pan and heated to $83^{\circ} \mathrm{C}$ (Wells, 2018). Once the temperature of the milk reached $83^{\circ} \mathrm{C}$, just before boiling point, the heat was turned down to low and simmered for 5 minutes. The heated milk was then cooled down to $44^{\circ} \mathrm{C}$ in an ice bath. While cooling down the milk, it was stirred gently to prevent skin forming (BC Dairy Association, n.d.). After the temperature of the milk reached $44^{\circ} \mathrm{C}$, $250 \mathrm{ml}$ of milk was transferred into 3 different $500 \mathrm{ml}$ beakers. Appropriate starter cultures were added to the beakers $(1.25 \mathrm{~g}$ of the commercial starter culture and 3 probiotic capsules) and mixed well. Each inoculated and noninoculated $250 \mathrm{ml}$ of milk were then poured into 3 clean glass shots and set in oven for 7 hours. The oven was pre- 
heated at $40^{\circ} \mathrm{C}$. The procedure was repeated 3 times.

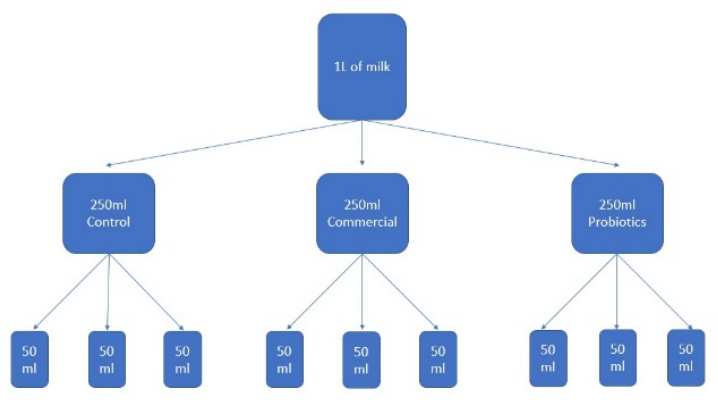

Fig. 2. Flow chart of the samples for an experiment.

\section{Measuring $\mathrm{pH}$ of the samples}

The $\mathrm{pH}$ of samples was measured repeatedly every 45 minutes during 7 hours of the incubation period using a Professional Portable Yogurt $\mathrm{pH}$ Meter (HI-98164) from Hanna Instruments. To increase the accuracy of the measurement, a three-point calibration was made with three standard buffer solutions with $\mathrm{pH}$ of 4.01, 7.01, and 10.1 (Hammel et al., 2016). The electrode was rinsed with distilled water and placed into the buffer solution. The CAL button was pressed, and the $\mathrm{pH}$ reading appeared in the display. Up or down keys were used to adjust the buffer value. When the $\mathrm{pH}$ reading became steady, a CFM functional key appeared and was pressed to confirm the first calibration value. Second and third calibrations were done followed by same procedure as the first calibration. Once all the calibrations were done, the instrument saved the calibration values and returned to normal mode (Hanna Instrument, n.d.). The standard buffer solution of $\mathrm{pH} 4.01,7.01$ and 10.1 were used to calibrate because the data were mostly measured from $\mathrm{pH}$ of 3 to 6 . The electrode was cleaned with distilled water between calibrations to rinse off all traces of the previous buffer solutions to prevent the possible measurement errors and produce valid and reliable data.

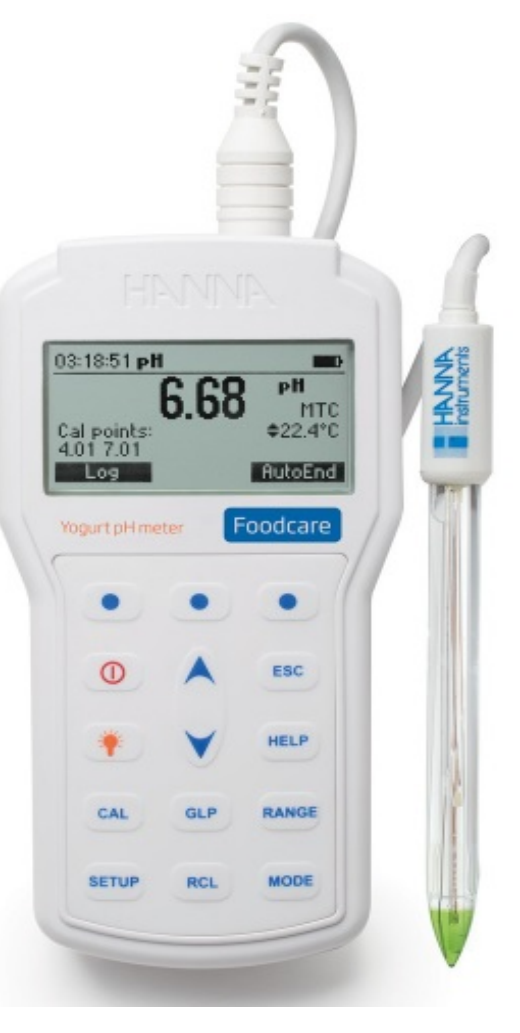


Fig. 3. Hanna Professional Portable Yogurt pH Meter (Hanna Instrument, n.d.).

Justification of methods

Spontaneous fermentation was

used for the true control to see if bacteria in milk is enough to initiate a fermentation. The commercial starter culture was chosen for the second group because they are largely available, and it is specifically used for making yogurt at home. For the third group, probiotics (Jamieson 10 Billions Probiotic) was chosen because it contains strains of bacteria that are capable of turning milk into yogurt such as Lactobacillus (Sarvari et al., 2014).

Each group has 3 samples; therefore, 10 readings of each sample will give 30 data points for each group which is enough to do statistical analysis. The experiment is repeated 3 times ( 3 times for control, 3 times for the commercial starter, and 3 times for probiotics). By repeating experiment 3 times, consistency of the results can be verified.

The amount of commercial starter culture used was decided based the product instructions. The amount of probiotics used was decided based on how much people usually use to make yogurt at home.

\section{Alternative Method}

Instead of measuring $\mathrm{pH}$ for every 45 minutes for 7 hours, all samples can be measured once after incubation period to see if the 7 hours of incubation period is enough for yogurt to reach $\mathrm{pH}$ below 4.6. The groups can be the same: control, commercial starter, and probiotics. Each group will have 30 samples. All the procedures will be repeated 3 times thus will be measuring 90 samples of $\mathrm{pH}$ of each group.

\section{Results}

Descriptive Statistics

The collected data were continuous numerical data. Each group of yogurts consisted of 3 samples and $\mathrm{pH}$ of each sample was measured and recorded every 45 minutes for 7 hours after the samples were placed in the oven for the incubation. Each sample consisted of 10 readings of $\mathrm{pH}$ measurements, and therefore each group has 30 readings of $\mathrm{pH}$ measurements. Below table.1A, 1B, and $1 \mathrm{C}$ are the summary of the mean, 
median, standard deviation and $\mathrm{max} / \mathrm{min}$ of the variables for each of the three experiments.

A

\begin{tabular}{|l|l|l|l|l|}
\hline & Mean & Median & SD & Max/Min \\
\hline Control pH & 6.519 & 6.505 & 0.05558 & $6.67 / 6.43$ \\
\hline $\begin{array}{l}\text { Commercial } \\
\text { Starter pH }\end{array}$ & 5.452 & 5.775 & 0.9576 & $6.65 / 4.02$ \\
\hline Probiotics pH & 5.477 & 5.482 & 0.6639 & $6.62 / 4.54$ \\
\hline
\end{tabular}

B

\begin{tabular}{|l|l|l|l|l|}
\hline & Mean & Median & SD & Max/Min \\
\hline Control pH & 6.509 & 6.490 & 0.05558 & $6.65 / 6.42$ \\
\hline $\begin{array}{l}\text { Commercial } \\
\text { Starter pH }\end{array}$ & 5.430 & 5.710 & 0.9576 & $6.69 / 4.03$ \\
\hline Probiotics pH & 5.487 & 5.385 & 0.6639 & $6.68 / 4.53$ \\
\hline
\end{tabular}

C

\begin{tabular}{|l|l|l|l|l|}
\hline & Mean & Median & SD & Max/Min \\
\hline Control pH & 6.485 & 6.485 & 0.07623 & $6.63 / 6.36$ \\
\hline $\begin{array}{l}\text { Commercial } \\
\text { Starter pH }\end{array}$ & 5.420 & 5.645 & 0.9548 & $6.61 / 4.09$ \\
\hline Probiotics pH & 5.481 & 5.415 & 0.6651 & $6.63 / 4.54$ \\
\hline
\end{tabular}

Table. 1. Descriptive Statistics of the first experiment $(A)$, the second experiment $(B)$, and the third experiment (C).

All the sample groups presented the same trend where $\mathrm{pH}$ decreased as incubation time increased. More specifically, samples with the commercial starter and the probiotics decreased $\mathrm{pH}$ rapidly within the 12 hours period. The standard deviation for the control group was the smallest followed by the probiotics group and the commercial starter group. On the other hand, an opposite trend of mean and median values was observed from the trend of standard deviation.

\section{ANOVA Inferential Statistics}

All the statistical analyses were carried out through NCSS software (Heacock, 2018 \& NCSS, 2018). A oneway ANOVA test (appendix A) was conducted to see if there were differences in means of different groups (Heacock, 2018). The null hypothesis (Ho) was there is no difference in $\mathrm{pH}$ between means of the control, commercial starter, and probiotics. The alternative hypothesis $\mathrm{(Ha}$ ) was at least two means of $\mathrm{pH}$ of the control, 
commercial starter, and probiotics are different.

The first and second experiment reports (appendix A) showed that the data were parametric and unequal variances therefore Welch's test was read. The $p$-values for the both experiments were 0.000001 which were less than 0.05 therefore null hypothesis was rejected and it could be concluded there statistically significant differences between at least two means of the groups. The power values were $99.9 \%$. Therefore, one could be confident that the results were true. There were not likely to be alpha errors and beta errors. Based on the Scheffe's MultipleComparison Test, the control group was different from the commercial starter group and the probiotics group while the commercial starter group and the probiotics group did not have a statistically significant difference.

The third experiment report (appendix A) showed different results from the first and the second experiment. The data were nonparametric and unequal variances; therefore, Kruskal-Wallis One-Way ANOVA was read. The $p$-value was 0.000001 . It is significantly smaller than
0.05 , therefore, the null hypothesis was rejected and concluded that there was a statistically significant difference between at least two means of the groups and there were not likely to be an alpha error. The power value was $99.9 \%$ indicating that results were most likely true and beta errors were not likely to exist. Like the first and second experiment, Scheffe's MultipleComparison Test remarked the control group was different from the commercial starter group and the probiotics group while the commercial starter group and the probiotics group didn't have statistically significant difference.

Repeated Measures ANOVA Inferential Statistics

Repeated Measures ANOVA test (appendix B) was used to compare means of $\mathrm{pH}$ of the groups within the time at which each measurement was made. There were three null and alternative hypotheses. The null hypotheses were that there is no significant difference between the $\mathrm{pH}$ of the groups (control, commercial, probiotics), there is no significant difference between the $\mathrm{pH}$ of the different measurement times $(0,45,90$, 
$135,180,225,270,315,360,405$

minute), and there is no significant

difference between the $\mathrm{pH}$ of the groups within the different measurement times.

The alternative hypotheses were that there is significant difference between the $\mathrm{pH}$ of the groups, there is significant difference between the $\mathrm{pH}$ of the different measurement times, and there is significant difference between the $\mathrm{pH}$ of the groups within the different measurement times.

Based on the Analysis of Variance Table (appendix B), the pvalues between the $\mathrm{pH}$ of the groups, the $\mathrm{pH}$ of the different measurement times, and the $\mathrm{pH}$ of the groups within the different measurement times were 0.0000001 , therefore, the null hypothesis were rejected and concluded that there were a statistically significant difference between the $\mathrm{pH}$ of the groups, the $\mathrm{pH}$ of the different measurement times, and the $\mathrm{pH}$ of the groups within the different measurement times. The power values were $99.9 \%$, therefore, the results were likely to be true, and alpha and beta error were not likely to exist.

A

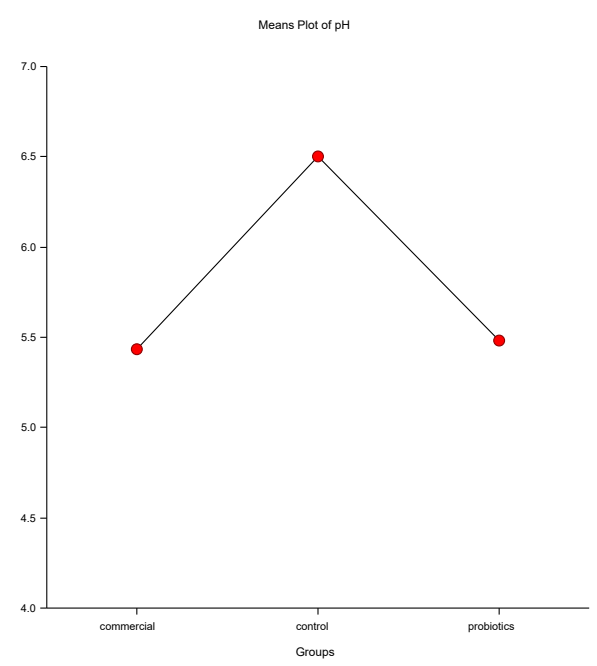

B

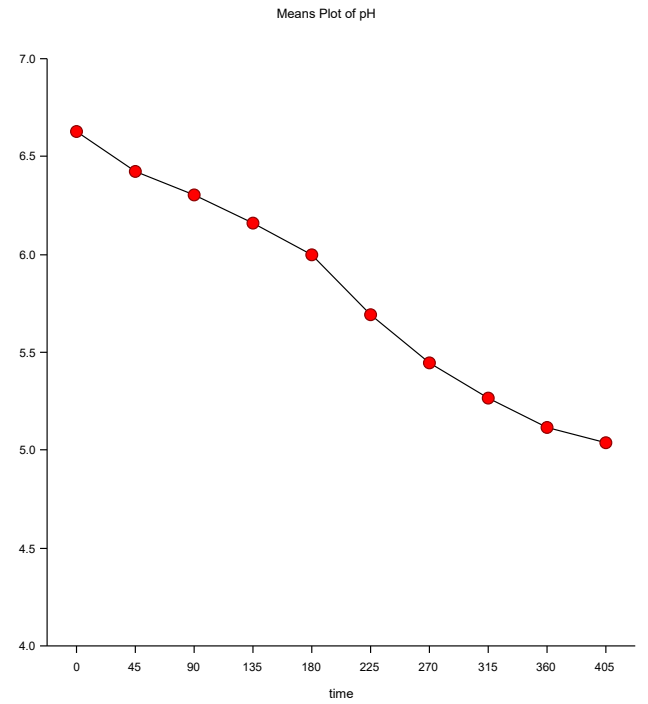


C

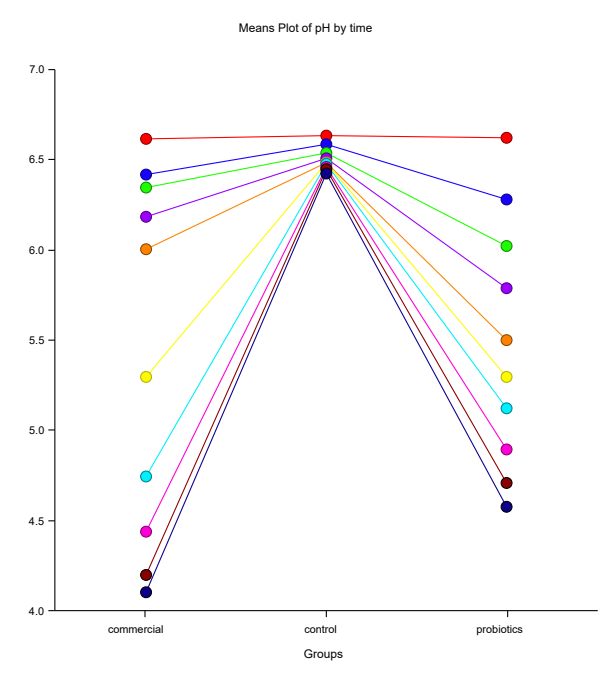

D

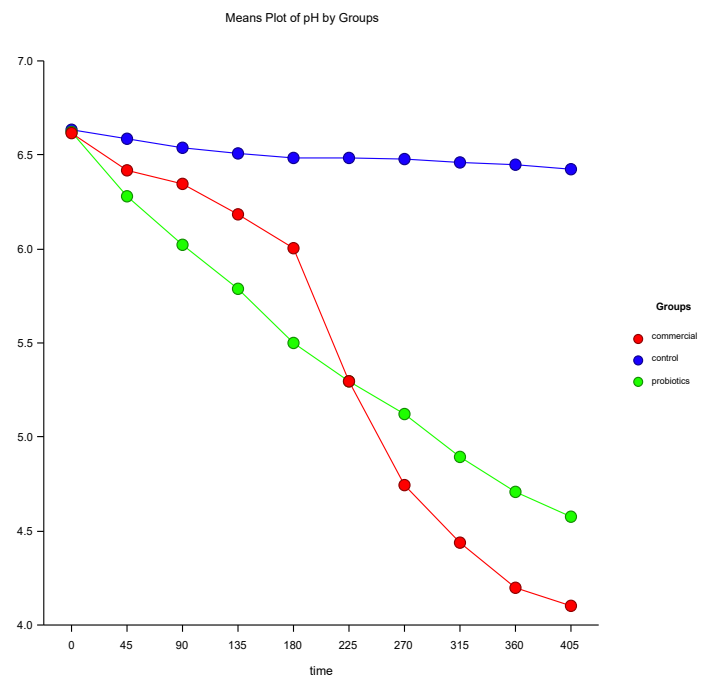

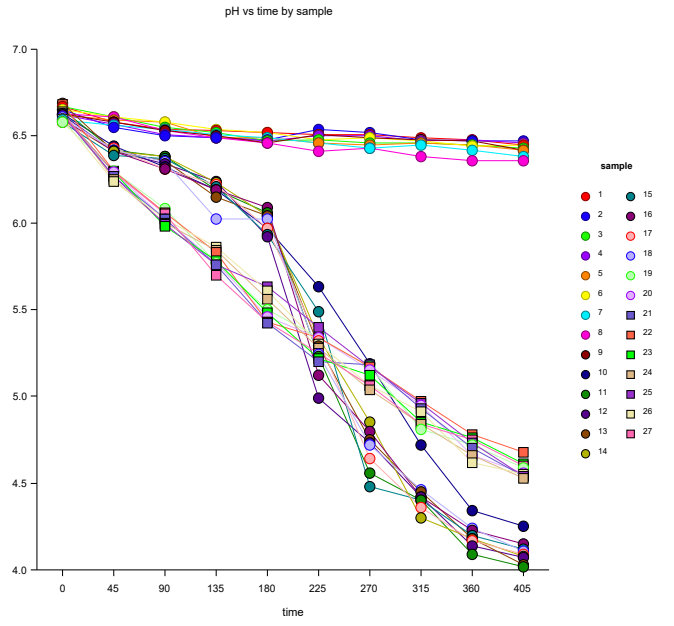

Fig. 4. Repeated Measures ANOVA test results plots. The means of the $\mathrm{pH}$ were plotted between the groups $(A)$, at the different measurement times (B), at the different measurement times within the groups $(C)$, for the groups within the different measurement times (D), and for all the individual sample within the different measurement times $(E)$.

As seen in Fig. 4A, the control group had the highest $\mathrm{pH}$ mean and the commercial starter group had the lowest $\mathrm{pH}$ mean. The overall trend of means of the $\mathrm{pH}$ was plotted in Fig. 4B. As seen in the Fig. 4B, the means of $\mathrm{pH}$ decreased over time. Fig. $4 C$ and $D$ clearly showed the comparison between the means of $\mathrm{pH}$ related to the groups and the different measurement times. 
As shown in the Fig. $4 C$ and $D$, the means of $\mathrm{pH}$ of the control and the probiotics group gradually decreased over time, however, the commercial starter culture group decreased the $\mathrm{pH}$ rapidly after 180 minutes of the incubation. Until 225 minutes of the incubation, the probiotics group $\mathrm{pH}$ means were lower than the means of the $\mathrm{pH}$ of the commercial starter culture group. After 225 minutes of the incubation, the commercial starter culture group $\mathrm{pH}$ means became lower than the probiotics group $\mathrm{pH}$ means (Fig. 4C and 4D). Similar pH changes of the samples were observed within the different groups (Fig. 4E).

The control group samples did not coagulate. The commercial starter group samples coagulated and formed firm yogurt. The probiotics group did coagulate but did not form firm yogurt. Average $\mathrm{pH}$ of all the control group samples after 7 hours of incubation was $6.43,4.10$ for the commercial starter group, and 4.58 for the probiotics group. The commercial starter group samples started to coagulate at 225 minutes and smelled like yogurt. Most of them completed coagulation at 270 minutes, formed thick creamy texture. The probiotics group samples started to coagulate at 180 minutes and smelled like yogurt at 225 minutes. However, even at 315 minutes the samples did not complete coagulation. At 405 minutes, the coagulations were not firm, they broke easily and did not formed thick creamy texture like the commercial starter group samples.

\section{Discussion}

Decrease in $\mathrm{pH}$ was observed in the all groups. The overall trends of decrease in $\mathrm{pH}$ of each samples had consistency within the groups. The control group $\mathrm{pH}$ gradually decreased over time. Pasteurized milk contains many bacteria that may contribute in a fermentation process (FDA 2019). However, due to not enough fermentation process, milk did not turn into a yogurt. Fermentation of milk require certain strains of bacteria such as Lactobacillus bulgaricus and Streptococcus thermophilus (Sodini et al., 2004). It was not certain that if the pasteurized milk used in the experiment, contains such bacteria furthermore, it is not sure if the bacteria survived the heating process of the procedure. However, as seen in the results one can 
suspect that the milk did not contain bacteria that are capable of initiating fermentation.

The results confirmed that the use of the commercial starter culture ensures an adequate $\mathrm{pH}$ for the safety of yogurts. As seen in the Fig. 4D, the first half of the incubation period, the commercial starter culture group decreased $\mathrm{pH}$ gradually but after 180 minutes $\mathrm{pH}$ started to decrease rapidly and as shown in the Fig. 4E, by 315 minutes most of the $\mathrm{pH}$ of samples were below 4.6 which is the level of $\mathrm{pH}$ that makes the fermented food safe (Mclntrye, 2016). The commercial starter culture, Yogourtmet, contains the strains of bacteria (Lactobacillus bulgaricus, Streptococcus thermophilus, and Lactobacillus acidophilus) that are capable of initiating fermentation of milk into a yogurt (Yogourtmet, n.d.; Sodini et al., 2004). Inoculation of bacteria abled rapid decrease in $\mathrm{pH}$ of yogurt. The average $\mathrm{pH}$ of the last reading was 4.1 which is below 4.6 and therefore comply with Fermented Food Safety Guideline (Mclntrye, 2016).

The use of probiotics capsules for yogurts fermentation decrease the $\mathrm{pH}$ at the level where it makes the yogurts safety to consume. The probiotics group showed gradual decrease in $\mathrm{pH}$ throughout the incubation period. The probiotics (Jamison, n.d.) used in the experiments contains many strains of probiotics such as a Lactobacillus acidophilus which is also contained in the commercial starter culture (Yogourtmet, n.d.) used in the experiment. Even though the probiotics contained many strains of bacteria, the formation of yogurt and degree of decrease in $\mathrm{pH}$ was not as good as the yogurt made with the commercial starter culture.

The decrease in $\mathrm{pH}$ occurs during fermentation because of microbial activities. In yogurt, lactose is converted into lactic acid by Lactobacillus bulgaricus, and streptococcus thermophilus and accumulation of lactic acid decrease the $\mathrm{pH}$ of the product (Russell and DiezGonzalez, 2008). The commercial starter culture contained all the strains that were necessary for a fermentation process to initiate, however, even though probiotics did not contain the strains that are capable of initiating a fermentation process, it was able to form coagulants. 


\section{Limitation}

Due to the design of the experiments required certain equipment (incubation oven, heating stove, basic kitchen utensils, pasteurized milk, commercial starter culture, probiotics supplement and $\mathrm{pH}$ meter), the experiments were done at the BCIT lab. The incubation oven used was little small to occupy large sample size. Therefore, the amount of milk used in each sample had to be reduced to fit the incubation oven. This may contribute an error in the experiment because inoculants may not be evenly distributed throughout the samples. This problem could have been solved if the experiment was conducted at the different location where it has big enough oven that can occupy larger volume of samples. However, the $\mathrm{pH}$ meter was not available to be used outside of the BCIT lab, therefore, samples must be kept in small volume.

The experiment required 7 hours of incubation period and due to the small size of incubation oven, the experiment had to be conducted for 3 days. Furthermore, the lab and the equipment were shared with other students, therefore, an arrangement was made with other students to utilize the lab. Like mentioned in the discussion, the probiotics used in the experiment contained Lactobacillus acidophilus which was also found in the commercial starter culture. However, within the designed incubation period, the average final $\mathrm{pH}$ measurement just met the standard safety $\mathrm{pH}$ level of 4.6. In order to see if the probiotics group further decreased the $\mathrm{pH}$ and formed more uniform texture of yogurt, the experiment need to last more than 7 hours.

\section{Future Research}

- Different brands of probiotics can be used as a starter culture for a yogurt and see if there are any difference in $\mathrm{pH}$.

- Different fermented food can be selected to see if use of probiotics and commercial start culture makes difference fermentation process for other foods.

- Inoculate samples with the strains that are known to initiate fermentation (Lactobacillus bulgaricus, Streptococcus thermophilus, and Lactobacillus 
acidophilus) individually and see $\mathrm{pH}$ difference in different strains.

\section{Conclusion}

The study showed that probiotics can be used as a starter culture for producing yogurt. Decrease in $\mathrm{pH}$ pattern was observed in all the groups. The $\mathrm{pH}$ changes pattern of the probiotics group showed gradual decrease in $\mathrm{pH}$ that indicates the fermentation process was in progress; the average of last $\mathrm{pH}$ reading after 7 hours of incubation period was 4.58 which was within the standard safe $\mathrm{pH}$ level. Recommendation can be provided to public that when making a yogurt using probiotics as a starter culture, ensure to incubate a inoculated milk for more than 7 hours to produce yogurt that is safe to consume. The commercial starter culture contained strains that were capable of initiating fermentation and the probiotics also contained a strain (Lactobacillus acidophilus) that was capable of initiating fermentation and contained in the commercial starter culture. Compare to the probiotics group, the $\mathrm{pH}$ of the commercial starter culture group decreased in more rapid rate. There was a significant difference between the $\mathrm{pH}$ of the groups within the different measurement times.

\section{Acknowledgements}

The study was supervised and supported by Helen Heacock and Fred Shaw from British Columbia Institute of Technology. The study was also supervised and supported by Aljosa Trmcic from BC Centre for Disease Control.

\section{Competing Interest}

The authors declare that they have no competing interests. 


\section{Reference}

Barbosa-cánovas, S. E. G. V. (2016). Novel Food Fermentation Technologies. https://doi.org/10.1007/978-3-31942457-6

BC Dairy Association. (n.d.). Make Your Own Yogurt. Retrieved from https://bcdairy.ca/milk/recipes/makeyour-own-yogurt

Chambers, P. J., \& Pretorius, I. S. (2010). Fermenting knowledge: The history of winemaking, science and yeast research. EMBO Reports. https://doi.org/10.1038/embor.2010.179

Christensen, E. (2018). How to Make Yogurt at Home. Kitchn. Retrieved from https://www.thekitchn.com/how-tomake-yogurt-at-home-cooking-lessonsfrom-the-kitchn-125070

FDA (2019). The Dangers of Raw Milk: Unpasteurized Milk Can Pose a Serious Health Risk. Retrieved from https://www.fda.gov/food/resourcesforyou/c onsumers/ucm079516.htm

Fijan, S. (2014). Microorganisms with claimed probiotic properties: An overview of recent literature. International Journal of Environmental Research and Public Health. https://doi.org/10.3390/ijerph110504745

Franz, C. M. A. P., Huch, M., Mathara, J. M., Abriouel, H., Benomar, N., Reid, G., Holzapfel, W. H. (2014). African fermented foods and probiotics. International Journal of Food Microbiology. https://doi.org/10.1016/j.ijfoodmicro.201 $\underline{4.08 .033}$
Gill, H. S., \& Guarner, F. (2004).

Probiotics and Human Health: A Clinical Perspective. Postgraduate Medical Journal.

https://doi.org/10.1136/pgmj.2003.00866 4

Hammel, R., Karakilic, V., \& Shaw, F. (2016). The Affect of Temperature and $\mathrm{pH}$ on the Food Safety of Kombucha Tea. Bcit Environmental Health Journal.

Hanna Instruments (n.d.). Food Quality $\mathrm{pH}$ Meters. Retrieved from https://hannainst.com/downloads/dl/file/i d/2226/waterproof food meters hanna. pdf

Heacock, H. (2018). Modules 4A. Research Methods ENVH 8400. BCIT

Heacock, H. (2018). Modules 4C. Research Methods ENVH 8400. BCIT

Jamieson (n.d.). 10 Billion ProbioticDaily maintenance. Retrieved from https://www.jamiesonvitamins.com/prod ucts/10-billion-probiotic

Kechagia, M., Basoulis, D., Konstantopoulou, S., Dimitriadi, D., Gyftopoulou, K., Skarmoutsou, N., \& Fakiri, E. M. (2013). Health Benefits of Probiotics: A Review. ISRN Nutrition. https://doi.org/10.5402/2013/481651

Kelesidis, T., \& Pothoulakis, C. (2012). Efficacy and safety of the probiotic Saccharomyces boulardii for the prevention and therapy of gastrointestinal disorders. Therapeutic Advances in Gastroenterology. https://doi.org/10.1177/1756283X11428 $\underline{502}$ 
Lee, J.-H., \& O'Sullivan, D. J. (2010). Genomic Insights into Bifidobacteria. Microbiology and Molecular Biology Reviews.

https://doi.org/10.1128/MMBR.00004-10

Lourens-Hattingh, A., \& Viljoen, B. C. (2001). Yogurt as probiotic carrier food. International Dairy Journal. https://doi.org/10.1016/S09586946(01)00036-X

Martín, R., Miquel, S., Ulmer, J., Kechaou, N., Langella, P., \& BermúdezHumarán, L. G. (2013). Role of commensal and probiotic bacteria in human health: A focus on inflammatory bowel disease. Microbial Cell Factories. https://doi.org/10.1186/1475-2859-12-71

Mataragas, M., Bellio, A., Rovetto, F., Astegiano, S., Decastelli, L., \& Cocolin, L. (2015). Risk-based control of foodborne pathogens Listeria monocytogenes and Salmonella enterica in the Italian fermented sausages Cacciatore and Felino. Meat Science.

https://doi.org/10.1016/j.meatsci.2015.0 1.002

Mattila-Sandholm, T., Myllärinen, P., Crittenden, R., Mogensen, G., Fondén, R., \& Saarela, M. (2002). Technological Challenges for Future Probiotic foods. In International Dairy Journal.

https://doi.org/10.1016/S0958-

6946(01)00099-1

McIntyre, L. (2016). Fermented Food Safety. BC Centre for Disease Control.

McNeil, B., \& Harvey, L. M. (2008). Practical Fermentation Technology. Practical Fermentation Technology. https://doi.org/10.1002/9780470725306
Minimalist Baker. (2017). How Easy 2Ingredient Coconut Yogurt. Retrieved from https://minimalistbaker.com/easy2-ingredient-coconut-yogurt/

NCSS. (2018). Statistical Software. Retrieved from https://www.ncss.com/

Ozen, M., \& Dinleyici, E. C. (2015). The history of probiotics: The untold story. Beneficial Microbes, 6(2), 159-165. https://doi.org/10.3920/BM2014.0103

Report, M. W. (2013). Botulism associated with home-fermented tofu in two Chinese immigrants--New York City, March-April 2012. MMWR. Morbidity and Mortality Weekly Report.

Russell, J. B., \& Diez-Gonzalez, F. (2008). The Effects of Fermentation Acids on Bacterial Growth. https://doi.org/10.1016/s00652911(08)60017-x

Sarvari, F., Mortazavian, A. M., Fazeli, M. R. (2014). Biochemical

Characteristics and Viability of Probiotic and Yogurt Bacteria in Yogurt during the Fermentation and Refrigerated Storage. Applied Food Biotechnology.

https://doi.org/10.22037/afb.v1i1.7125

Sodini, I., Remeuf, F., Haddad, C., \& Corrieu, G. (2004). The Relative Effect of Milk Base, Starter, and Process on Yogurt Texture: A Review. Critical Reviews in Food Science and Nutrition. https://doi.org/10.1080/1040869049042 4793

Tseng, C. K., Tsai, C. H., Tseng, C. H., Tseng, Y. C., Lee, F. Y., \& Huang, W. S. (2009). An outbreak of foodborne botulism in Taiwan. International Journal of Hygiene and Environmental Health. 
https://doi.org/10.1016/j.ijheh.2008.01.0

$\underline{02}$

Ursell, L. K., Metcalf, J. L., Parfrey, L. W., \& Knight, R. (2012). Defining the human microbiome. Nutrition Reviews, 70, S38-S44.

https://doi.org/10.1111/j.1753-

4887.2012.00493.x

Wells, K. (2018). How to Make Yogurt (Easy Homemade Recipe). Wellness
Mama. Retrieved from

https://wellnessmama.com/59276/yogurt -recipe/

Yogourtmet (n.d.). Original Yogurt Starter. Retrieved from http://www.yogourmet.com/caen/yogurt-starter-culture.php 


\section{Appendix A}

NCSS 12.0.9

One-Way Analysis of Variance Report

Dataset

Response
Untitled

control1,commercial1, probiotics1

Tests of the Normality of Residuals Assumption

\begin{tabular}{|c|c|c|c|}
\hline Normality Attributes & $\begin{array}{l}\text { Test } \\
\text { Value }\end{array}$ & $\begin{array}{l}\text { Prob } \\
\text { Level }\end{array}$ & $\begin{array}{l}\text { Reject Normality? } \\
(\alpha=0.20)\end{array}$ \\
\hline Skewness & -0.5784 & 0.56297 & No \\
\hline Kurtosis & -0.9917 & 0.32135 & No \\
\hline Skewness and Kurtosis (Omnibus) & 1.3180 & 0.51736 & No \\
\hline
\end{tabular}

Tests of the Equality of Group Variances Assumption

$\begin{array}{lrrl} & \begin{array}{r}\text { Test } \\ \text { Value }\end{array} & \begin{array}{r}\text { Prob } \\ \text { Level }\end{array} & \begin{array}{l}\text { Reject Equal Variances? } \\ \text { (a=0.20) }\end{array} \\ \text { Test Name } & 41.1358 & 0.00000 & \text { Yes } \\ \text { Brown-Forsythe (Data - Medians) } & 68.0091 & 0.00000 & \text { Yes } \\ \text { Levene (Data - Means) } & 49.9248 & 0.00000 & \text { Yes } \\ \text { Conover (Ranks of Deviations) } & 123.2258 & 0.00000 & \text { Yes } \\ \text { Bartlett (Likelihood Ratio) } & & & \end{array}$

\section{Box Plot Section}

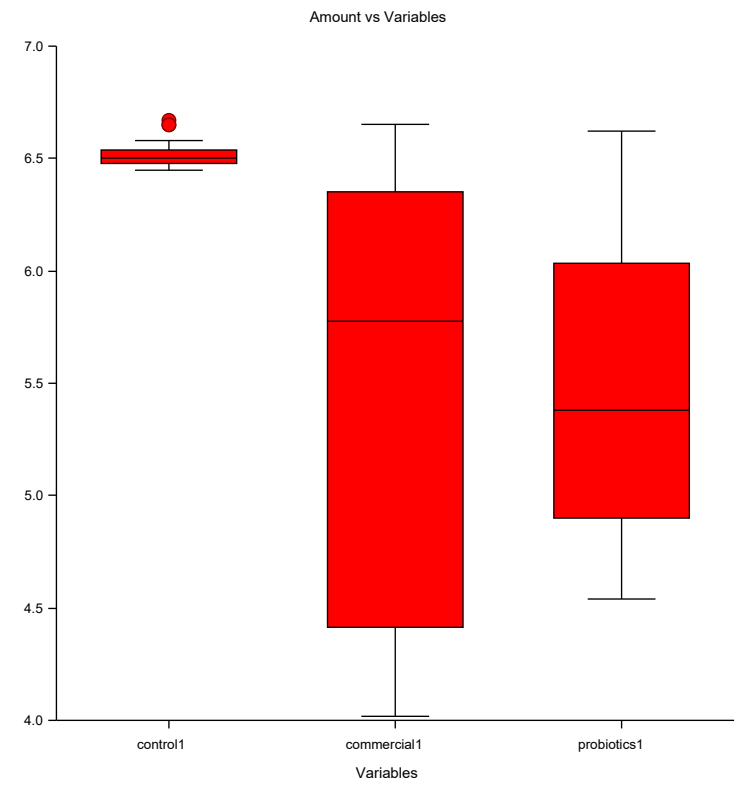




\section{One-Way Analysis of Variance Report}

Dataset Untitled

Response control1,commercial1,probiotics1

Expected Mean Squares Table

\begin{tabular}{lllll}
\hline & & & & \\
Model & & Term & Denominator & Expected \\
Term & DF & Fixed? & Term & Mean Square \\
A $(\ldots)$ & 2 & Yes & $\sigma^{2}$ & $\sigma^{2}+s A$ \\
Error & 87 & No & & $\sigma^{2}$
\end{tabular}

Note: Expected Mean Squares are for the balanced cell-frequency case.

Analysis of Variance Table and F-Test

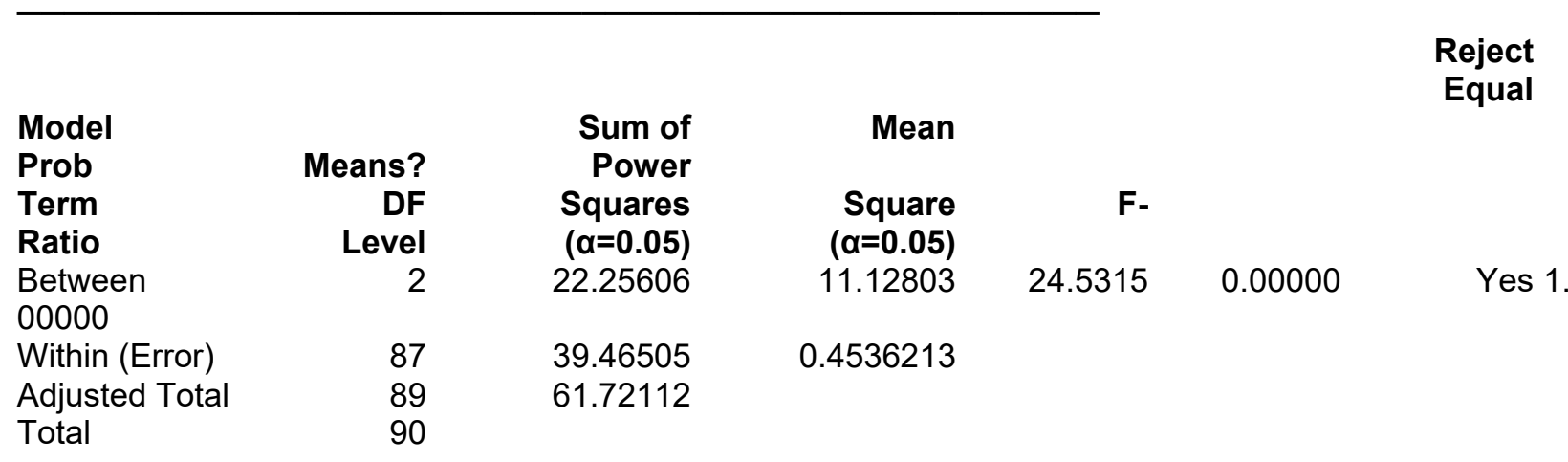

Welch's Test of Means Allowing for Unequal Variances

\begin{tabular}{lrrrrr}
\hline $\begin{array}{l}\text { Model } \\
\text { Means? }\end{array}$ & Numerator & Denominator & & Prob & Reject Equal \\
$\begin{array}{l}\text { Term } \\
\text { Between Groups }\end{array}$ & DF & DF & F-Ratio & Level & $(\mathbf{\alpha = 0 . 0 5 )}$ \\
& 2 & 39.06 & 54.0931 & 0.00000 & Yes
\end{tabular}

\section{Kruskal-Wallis One-Way ANOVA on Ranks}

\section{Hypotheses}

HO: All medians are equal.

$\mathrm{H} 1$ : At least two medians are different.

Test Results

Method

Not Corrected for Ties

Corrected for Ties

Number Sets of Ties

$\begin{array}{rrrl}\text { DF } & \begin{array}{r}\text { Chi-Squared } \\ \mathbf{( H )}\end{array} & \begin{array}{r}\text { Prob } \\ \text { Level }\end{array} & \begin{array}{l}\text { Reject H0? } \\ (\mathbf{\alpha = 0 . 0 5 )}\end{array} \\ 2 & 39.8480 & 0.00000 & \text { Yes } \\ 2 & 39.8677 & 0.00000 & \text { Yes }\end{array}$

17 


\section{Group Detail}

Group

control1

commercial1

probiotics 1

NCSS 12.0.9

$\begin{array}{rrrrr}\text { Count } & \begin{array}{r}\text { Sum of } \\ \text { Ranks }\end{array} & \begin{array}{r}\text { Mean } \\ \text { Rank }\end{array} & \text { Z-Value } & \text { Median } \\ 30 & 2102.50 & 70.08 & 6.3124 & 6.505 \\ 30 & 1000.00 & 33.33 & -3.1241 & 5.775 \\ 30 & 992.50 & 33.08 & -3.1883 & 5.38\end{array}$

2019-02-17 3:15:53 PM 3

One-Way Analysis of Variance Report

Dataset Untitled

Response control1,commercial1, probiotics1

\section{Normal Scores Tests}

\section{Hypotheses}

$\mathrm{HO}$ : All group data distributions are the same.

$\mathrm{H} 1$ : At least one group has observations that tend to be greater than those of the other groups.

\section{Results}

Test

$\begin{array}{rrrl}\text { DF } & \begin{array}{r}\text { Chi-Squared } \\ \mathbf{( H )}\end{array} & \begin{array}{r}\text { Prob } \\ \text { Level }\end{array} & \begin{array}{l}\text { Reject H0? } \\ (\mathbf{\alpha = 0 . 2 0 )}\end{array} \\ 2 & 32.7469 & 0.00000 & \text { Yes } \\ 2 & 33.1910 & 0.00000 & \text { Yes }\end{array}$

Descriptive Statistics

\section{Standard}

Group

All

A:

control1 30

commercial1 30

probiotics1
30

$\begin{array}{r}\text { Count } \\ \text { (ni) }\end{array}$
90

30
30
30

$\begin{array}{rr}\text { Mean } & \text { Effect } \\ 5.816222 & 5.816222 \\ & \\ 6.519333 & 0.7031111 \\ 5.452 & -0.3642222 \\ 5.477334 & -0.3388889\end{array}$

Standard

Median

6.505

5.775

5.38
Deviation

0.05558053

0.9576242

0.6638754
Error

$\sqrt{ }($ MSE/ni)

0.1229663

0.1229663

0.1229663

Plots of Means Section 


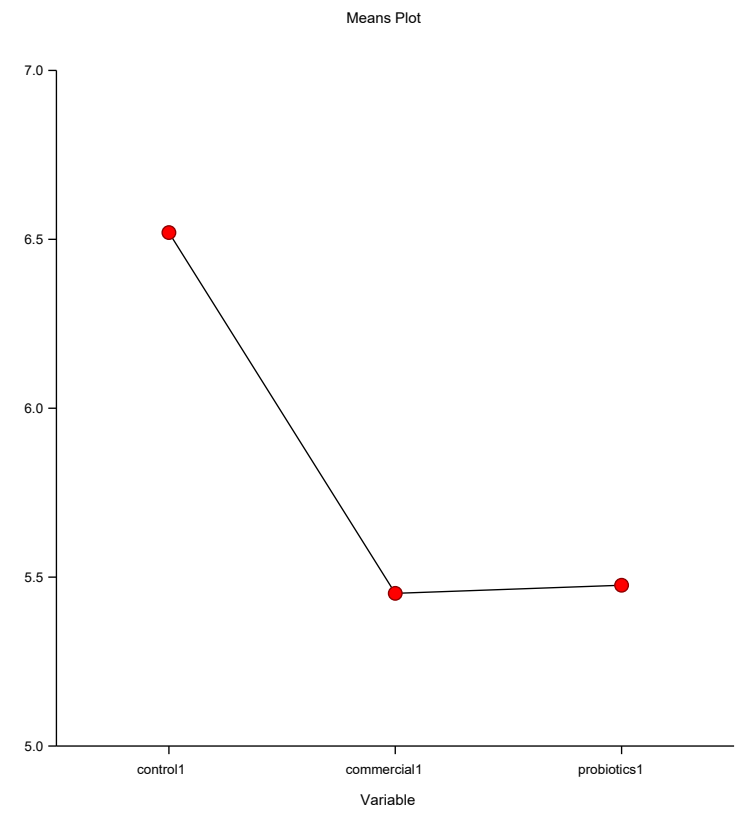

NCSS 12.0.9

\section{One-Way Analysis of Variance Report}

$\begin{array}{ll}\text { Dataset } & \text { Untitled } \\ \text { Response } & \text { control1,commercial1, probiotics1 }\end{array}$

\section{Scheffe's Multiple-Comparison Test}

Response: control1,commercial1,probiotics1

Term A:

Alpha=0.050 Error Term=S(A) DF=87 MSE=0.4536213 Critical Value=2.4905

$\begin{array}{llll}\text { Group } & \text { Count } & \text { Mean } & \begin{array}{l}\text { Different From } \\ \text { Groups }\end{array} \\ \text { control1 } & 30 & 6.519333 & \text { commercial1, probiotics1 } \\ \text { commercial1 } & 30 & 5.452 & \text { control1 } \\ \text { probiotics1 } & 30 & 5.477334 & \text { control1 }\end{array}$

Notes:

This report provides multiple comparison tests for all possible contrasts among the the means. These contrasts may involve more groups than just each pair, so the method is much stricter than need be. The Tukey-Kramer method provides more accurate results when only pairwise comparisons are needed.

\section{Tukey-Kramer Multiple-Comparison Test}

Response: control1,commercial1,probiotics1 
Term A:

Alpha $=0.050$ Error Term $=S(A) \quad D F=87$ MSE $=0.4536213$ Critical Value $=3.3796$

$\begin{array}{llll}\text { Group } & \text { Count } & \text { Mean } & \begin{array}{l}\text { Different From } \\ \text { Groups }\end{array} \\ \text { control1 } & 30 & 6.519333 & \text { commercial1, probiotics1 } \\ \text { commercial1 } & 30 & 5.452 & \text { control1 } \\ \text { probiotics1 } & 30 & 5.477334 & \text { control1 }\end{array}$

Notes:

This report provides multiple comparison tests for all pairwise differences between the means.

\section{Kruskal-Wallis Multiple-Comparison Z-Value Test (Dunn's Test)}

$\begin{array}{llll}\text { Variable } & \text { control1 } & \text { commercial1 } & \text { probiotics1 } \\ \text { control1 } & 0.0000 & 5.4495 & 5.4866 \\ \text { commercial1 } & 5.4495 & 0.0000 & 0.0371 \\ \text { probiotics1 } & 5.4866 & 0.0371 & 0.0000\end{array}$

Regular Test: Medians significantly different if z-value $>1.9600$

Bonferroni Test: Medians significantly different if $z$-value $>2.3940$

NCSS 12.0 .9

\section{One-Way Analysis of Variance Report}

Dataset Untitled

Response control1,commercial1, probiotics1

\section{Procedure Input Settings}

\section{Autosaved Template File}

C:IUsersISunghoolDocumentsINCSS 12/Procedure Templates\AutosavelOne-Way Analysis of Variance Autosaved 2019_2_17-15_15_54.t5

Variables Tab

Input Type

Response Variable(s) and a Factor (Grouping)

Variable

-- Variables

Response Variable(s)

control1, commercial1, probiotics1

Factor Variable

$<$ Empty>

-- Comparisons

-----

Planned Comparisons

None

Reports Tab

-- Select Reports

Assumptions (Normality and Equal Variance)

Checked 
Reports

EMS Report Checked

ANOVA Report Checked

Welch's Test Checked

Kruskal-Wallis / Van der Waerden / Checked

Terry-Hoeffding Tests

Means Report Checked

* Alpha

Test Alpha

0.05

Assumption Alpha

0.20

-- Multiple Comparison Tests

Bonferroni Test (All Pairs)

Bonferroni Test (Versus Control)

Unchecked

Unchecked

Dwass-Steel-Critchlow-Fligner Test

Unchecked

Duncan's Test

Dunnett's 2-Sided (Versus Control)

Unchecked

Dunnett's Lower 1-Sided (Versus Control)

Unchecked

Dunnett's Upper 1-Sided (Versus Control)

Unchecked

Unchecked

Dunnett's Confidence Intervals

Unchecked

Fisher's LSD Test

Hsu's M.C. with Best

Kruskal-Wallis Z Test (Dunn's Test)

Unchecked

Unchecked

Newman-Keuls Test

Checked

Scheffe's Test

Unchecked

Tukey-Kramer Test

Checked

Tukey-Kramer Confidence Intervals and P-Values

Checked

Unchecked

.. Multiple Comparison Alpha and Decimals

$\begin{array}{ll}\text { MC Alpha } & 0.05 \\ \text { MC Decimals } & \text { All }\end{array}$

NCSS 12.0.9

\section{One-Way Analysis of Variance Report}

Dataset Untitled

Response control1,commercial1,probiotics1

Procedure Input Settings (Continued)

Report Options Tab

-- Report Options

Variable Names

Value Labels

Names

Data Values

-- Decimal Places

Means and C.I. Limits

Std Deviations and Std Errors

Auto (Up to 7)

Auto (Up to 7) 
P-Values

Test Statistics

Rank Statistics

Fractional DF

$\alpha$ in Titles
5

4

2

2

2

Plots Tab

-- Select Plots

------

Means Plot

Checked

Box Plot

Checked

Storage Tab

-- Data Storage Options

Storage Option

Do not store data

NCSS 12.0.9

One-Way Analysis of Variance Report

Dataset Untitled

Response control2,commercial2,probiotics2

Tests of the Normality of Residuals Assumption

\begin{tabular}{lrrl}
\hline & & \\
& $\begin{array}{r}\text { Test } \\
\text { Value }\end{array}$ & $\begin{array}{r}\text { Prob } \\
\text { Level }\end{array}$ & $\begin{array}{l}\text { Reject Normality? } \\
\text { (a=0.20) }\end{array}$ \\
Skermality Attributes & -0.4994 & 0.61747 & No \\
Kurtosis & -1.1733 & 0.24069 & No \\
Skewness and Kurtosis (Omnibus) & 1.6260 & 0.44353 & No
\end{tabular}

Tests of the Equality of Group Variances Assumption

\begin{tabular}{|c|c|c|c|}
\hline Test Name & $\begin{array}{r}\text { Test } \\
\text { Value }\end{array}$ & $\begin{array}{l}\text { Prob } \\
\text { Level }\end{array}$ & $\begin{array}{l}\text { Reject Equal Variances? } \\
(\alpha=0.20)\end{array}$ \\
\hline Brown-Forsythe (Data - Medians) & 46.8517 & 0.00000 & Yes \\
\hline Levene (Data - Means) & 67.1249 & 0.00000 & Yes \\
\hline Conover (Ranks of Deviations) & 50.4080 & 0.00000 & Yes \\
\hline Bartlett (Likelihood Ratio) & 118.5104 & 0.00000 & Yes \\
\hline
\end{tabular}

Box Plot Section 


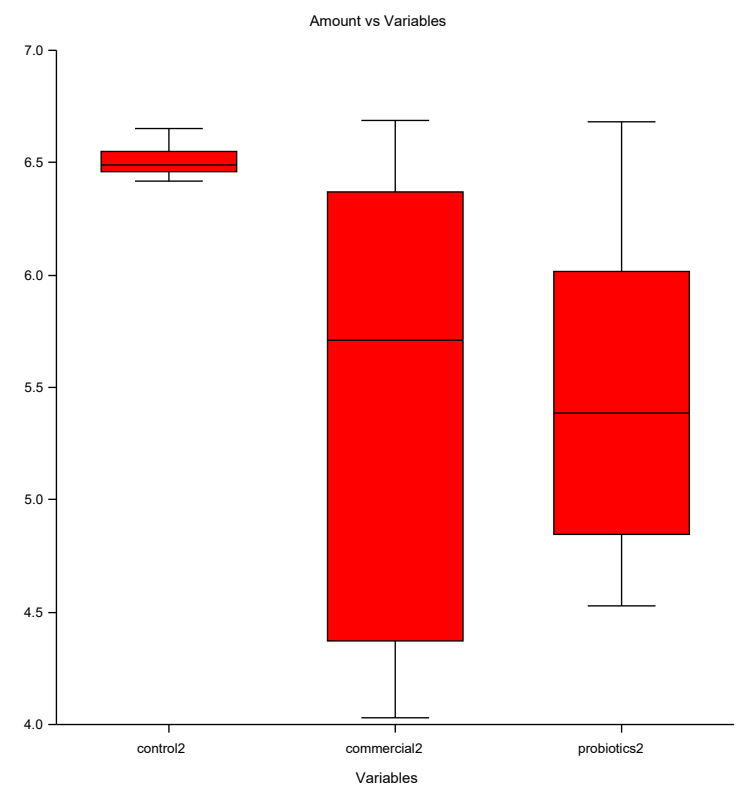

NCSS 12.0.9

One-Way Analysis of Variance Report

Dataset Untitled

Response control2,commercial2,probiotics2

Expected Mean Squares Table

$\begin{array}{lllll}\text { Model } & \text { DF } & \begin{array}{l}\text { Term } \\ \text { Fixed? }\end{array} & \begin{array}{l}\text { Denominator } \\ \text { Term }\end{array} & \begin{array}{l}\text { Expected } \\ \text { Mean Square }\end{array} \\ \text { Term } & 2 & \text { Yes } & \sigma^{2} & \sigma^{2}+s A \\ \text { A }(\ldots) & 87 & \text { No } & & \sigma^{2} \\ \text { Error } & 87 & & \end{array}$

Note: Expected Mean Squares are for the balanced cell-frequency case.

Analysis of Variance Table and F-Test

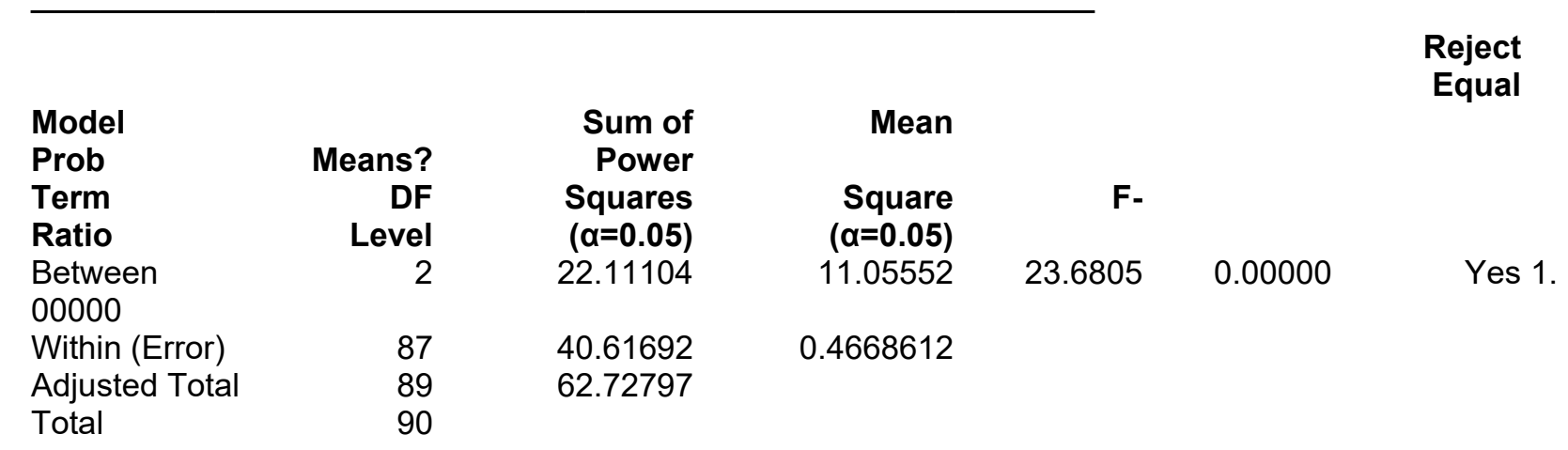

Welch's Test of Means Allowing for Unequal Variances 


$\begin{array}{lrrrrl}\begin{array}{l}\text { Model } \\ \text { Means? }\end{array} & \text { Numerator } & \text { Denominator } & & \text { Prob } & \text { Reject Equal } \\ \text { Term } & \text { DF } & \text { DF } & \text { F-Ratio } & \text { Level } & (\boldsymbol{\alpha}=\mathbf{0 . 0 5 )} \\ \text { Between Groups } & 2 & 39.15 & 52.1587 & 0.00000 & \text { Yes }\end{array}$

Kruskal-Wallis One-Way ANOVA on Ranks

Hypotheses

H0: All medians are equal.

$\mathrm{H} 1$ : At least two medians are different.

Test Results

Method

Not Corrected for Ties

Corrected for Ties

Number Sets of Ties

Multiplicity Factor

Group Detail

\section{Group}

control2

commercial2

probiotics2

NCSS 12.0.9

$\begin{array}{rrrl}\text { DF } & \begin{array}{r}\text { Chi-Squared } \\ (\mathbf{H})\end{array} & \begin{array}{r}\text { Prob } \\ \text { Level }\end{array} & \begin{array}{l}\text { Reject H0? } \\ (\mathbf{\alpha = 0 . 0 5 )}\end{array} \\ 2 & 39.2686 & 0.00000 & \text { Yes } \\ 2 & 39.2792 & 0.00000 & \text { Yes }\end{array}$

15

198

$\begin{array}{rrr}\text { Count } & \begin{array}{r}\text { Sum of } \\ \text { Ranks }\end{array} & \begin{array}{c}\text { Mean } \\ \text { Rank }\end{array} \\ 30 & 2097.00 & 69.90 \\ 30 & 987.00 & 32.90 \\ 30 & 1011.00 & 33.70\end{array}$

$\begin{array}{rr}\text { Z-Value } & \text { Median } \\ 6.2653 & 6.49 \\ -3.2354 & 5.71 \\ -3.0300 & 5.385\end{array}$

2019-02-17 3:37:12 PM 3

\section{One-Way Analysis of Variance Report}

Dataset Untitled

Response control2,commercial2,probiotics2

Normal Scores Tests

\section{Hypotheses}

$\mathrm{HO}$ : All group data distributions are the same.

$\mathrm{H} 1$ : At least one group has observations that tend to be greater than those of the other groups.

\section{Results}

Test

Terry-Hoeffding - Expected Normal Scores

Van der Waerden - Normal Quantiles

$\begin{array}{rrrl}\text { DF } & \begin{array}{r}\text { Chi-Squared } \\ \mathbf{( H )}\end{array} & \begin{array}{r}\text { Prob } \\ \text { Level }\end{array} & \begin{array}{l}\text { Reject H0? } \\ (\mathbf{\alpha}=\mathbf{0 . 2 0})\end{array} \\ 2 & 30.0151 & 0.00000 & \text { Yes } \\ 2 & 30.8110 & 0.00000 & \text { Yes }\end{array}$

Descriptive Statistics

\section{Standard}




$\begin{array}{lrrrrrr}\text { Group } & \begin{array}{r}\text { Count } \\ \text { (ni) }\end{array} & \begin{array}{r}\text { Mean } \\ \text { All }\end{array} & \begin{array}{r}\text { Effect } \\ \text { Median }\end{array} & \begin{array}{r}\text { Standard } \\ \text { Deviation }\end{array} & \begin{array}{r}\text { Error } \\ \text { (MSE/ni) }\end{array} \\ \text { A: } & 90 & 5.808778 & 5.808778 & & & \\ \text { control2 } & & & & & & \\ \text { commercial2 } & 30 & 6.509 & 0.7002222 & 6.49 & 0.06166372 & 0.1247479 \\ \text { probiotics2 } & 30 & 5.430666 & -0.3781111 & 5.71 & 0.9769302 & 0.1247479 \\ & 30 & 5.486667 & -0.3221111 & 5.385 & 0.6651229 & 0.1247479\end{array}$

\section{Plots of Means Section}

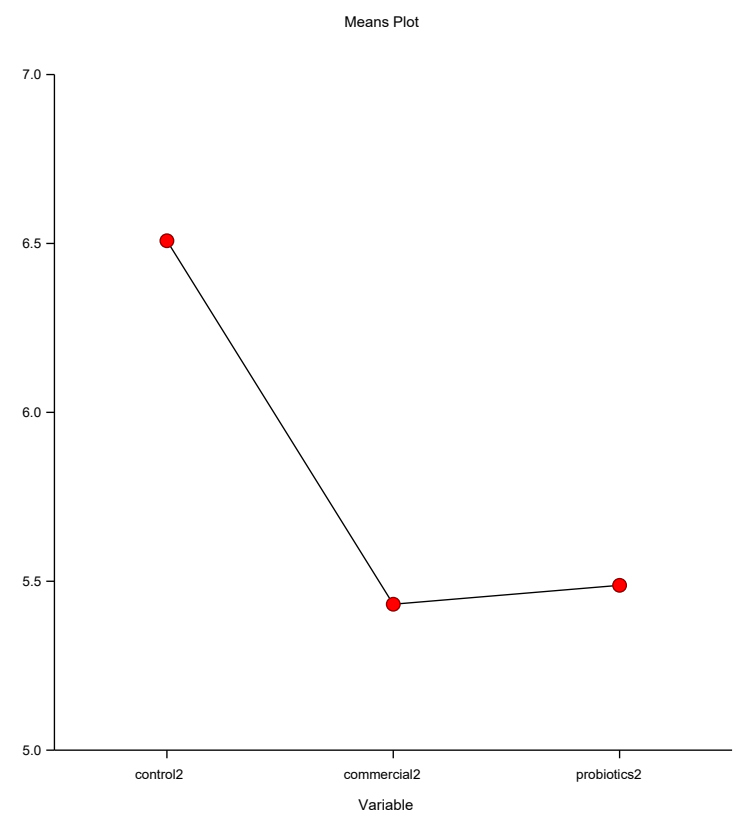

NCSS 12.0.9

One-Way Analysis of Variance Report

Dataset Untitled

Response control2,commercial2,probiotics2

Scheffe's Multiple-Comparison Test

Response: control2,commercial2,probiotics2

Term A:

Alpha $=0.050$ Error Term $=S(A) \quad D F=87$ MSE $=0.4668612$ Critical Value $=2.4905$

\section{Group}

control2

commercial2

probiotics2

$\begin{array}{ll}\text { Count } & \text { Mean } \\ 30 & 6.509 \\ 30 & 5.430666 \\ 30 & 5.486667\end{array}$

\section{Different From}

Groups

commercial2, probiotics2

control2

control2 
Notes:

This report provides multiple comparison tests for all possible contrasts among the the means. These contrasts may involve more groups than just each pair, so the method is much stricter than need be. The Tukey-Kramer method provides more accurate results when only pairwise comparisons are needed.

\section{Tukey-Kramer Multiple-Comparison Test}

Response: control2,commercial2,probiotics2

Term A:

Alpha $=0.050$ Error Term $=S(A) \quad D F=87$ MSE $=0.4668612$ Critical Value $=3.3796$

$\begin{array}{llll}\text { Group } & \text { Count } & \text { Mean } & \begin{array}{l}\text { Different From } \\ \text { Groups }\end{array} \\ \text { control2 } & 30 & 6.509 & \text { commercial2, probiotics2 } \\ \text { commercial2 } & 30 & 5.430666 & \text { control2 } \\ \text { probiotics2 } & 30 & 5.486667 & \text { control2 }\end{array}$

Notes:

This report provides multiple comparison tests for all pairwise differences between the means.

\section{Kruskal-Wallis Multiple-Comparison Z-Value Test (Dunn's Test)}

$\begin{array}{llll}\text { Variable } & \text { control2 } & \text { commercial2 } & \text { probiotics2 } \\ \text { control2 } & 0.0000 & 5.4860 & 5.3674 \\ \text { commercial2 } & 5.4860 & 0.0000 & 0.1186 \\ \text { probiotics2 } & 5.3674 & 0.1186 & 0.0000\end{array}$

Regular Test: Medians significantly different if z-value $>1.9600$

Bonferroni Test: Medians significantly different if z-value $>2.3940$

NCSS 12.0.9

\section{One-Way Analysis of Variance Report}

Dataset Untitled

Response control2,commercial2,probiotics2

\section{Procedure Input Settings}

\section{Autosaved Template File}

C:IUsers ISunghoolDocumentsINCSS 12\Procedure Templates\AutosavelOne-Way Analysis of Variance Autosaved 2019_2_17-15_37_13.t5

\section{Variables Tab}

Input Type

Response Variable(s) and a Factor (Grouping)

Variable

-- Variables 


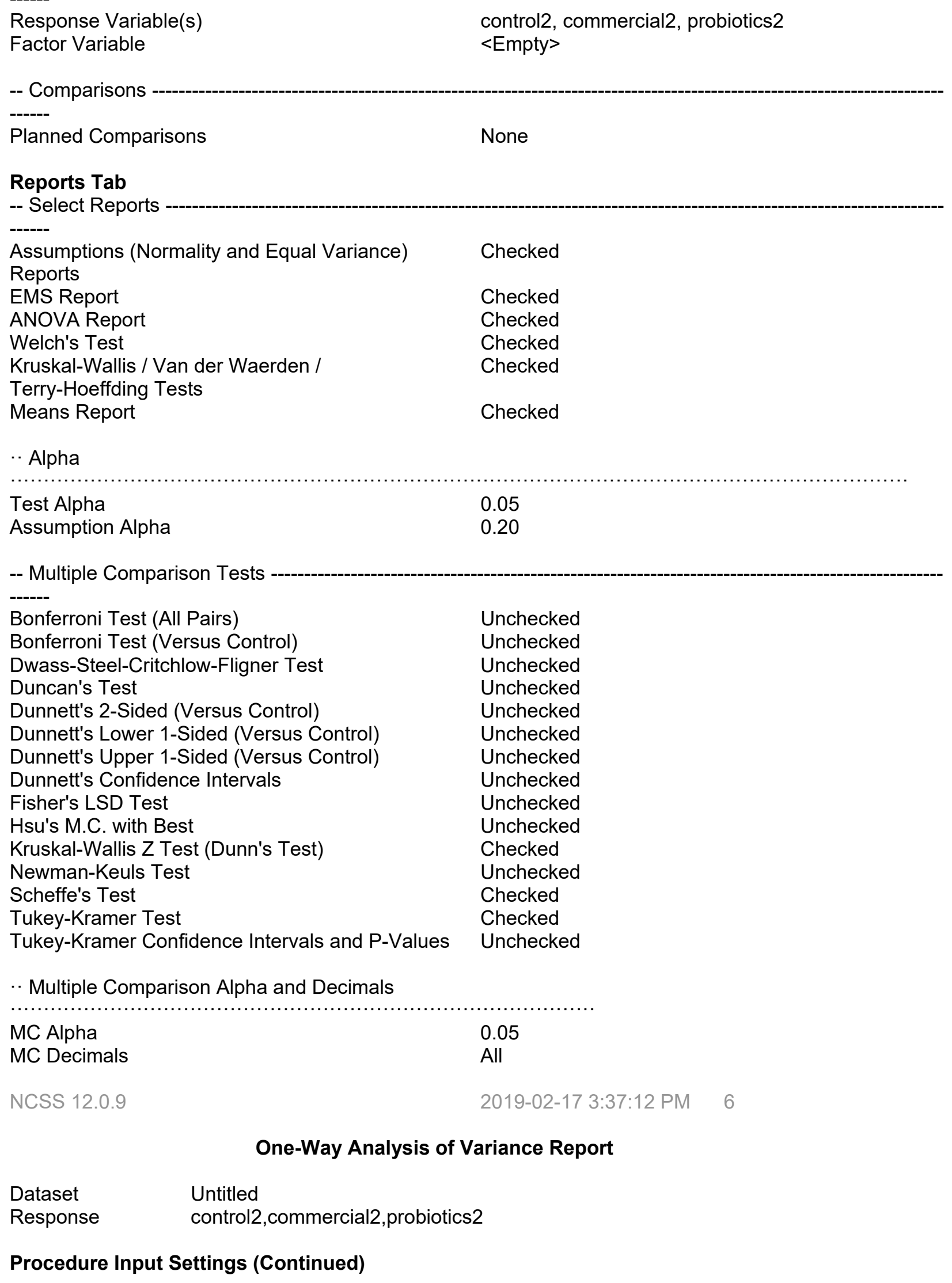


Report Options Tab

-- Report Options

------

Variable Names

Value Labels

Names

Data Values

-- Decimal Places

------

Means and C.I. Limits

Std Deviations and Std Errors

P-Values

Test Statistics

Rank Statistics

Fractional DF

$\alpha$ in Titles

Auto (Up to 7)

Auto (Up to 7)

5

4

2

2

2

Plots Tab

-- Select Plots

------

Means Plot

Checked

Box Plot

Checked

Storage Tab

-- Data Storage Options

Storage Option

Do not store data

NCSS 12.0.9

One-Way Analysis of Variance Report

Dataset Untitled

Response control3,commercial3,probiotics3

Tests of the Normality of Residuals Assumption

\begin{tabular}{lrrl}
\hline & & & \\
Normality Attributes & $\begin{array}{r}\text { Test } \\
\text { Value }\end{array}$ & $\begin{array}{r}\text { Prob } \\
\text { Level }\end{array}$ & $\begin{array}{l}\text { Reject Normality? } \\
(\mathbf{\alpha}=\mathbf{0 . 2 0})\end{array}$ \\
Skewness & -0.3618 & 0.71749 & No \\
Kurtosis & -1.4343 & 0.15149 & Yes \\
Skewness and Kurtosis (Omnibus) & 2.1881 & 0.33486 & No
\end{tabular}

Tests of the Equality of Group Variances Assumption

\begin{tabular}{|c|c|c|c|}
\hline Test Name & $\begin{array}{l}\text { Test } \\
\text { Value }\end{array}$ & $\begin{array}{l}\text { Prob } \\
\text { Level }\end{array}$ & $\begin{array}{l}\text { Reject Equal Variances? } \\
(\alpha=0.20)\end{array}$ \\
\hline Brown-Forsythe (Data - Medians) & 55.6505 & 0.00000 & Yes \\
\hline Levene (Data - Means) & 71.4001 & 0.00000 & Yes \\
\hline Conover (Ranks of Deviations) & 51.7383 & 0.00000 & Yes \\
\hline Bartlett (Likelihood Ratio) & 105.1375 & 0.00000 & Yes \\
\hline
\end{tabular}




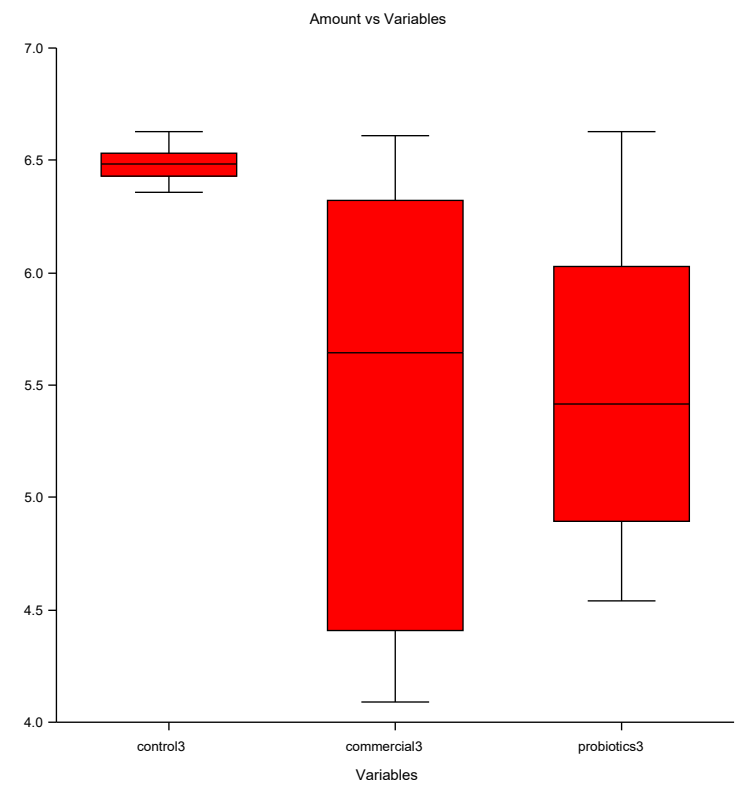

NCSS 12.0.9

One-Way Analysis of Variance Report

Dataset Untitled

Response control3,commercial3,probiotics3

\section{Expected Mean Squares Table}

$\begin{array}{lllll}\text { Model } & \text { DF } & \begin{array}{l}\text { Term } \\ \text { Fixed? }\end{array} & \begin{array}{l}\text { Denominator } \\ \text { Term }\end{array} & \begin{array}{l}\text { Expected } \\ \text { Mean Square }\end{array} \\ \text { Term } & 2 & \text { Yes } & \sigma^{2} & \sigma^{2}+s A \\ \text { A }(\ldots) & 87 & \text { No } & & \sigma^{2} \\ \text { Error } & 87 & & \end{array}$

Note: Expected Mean Squares are for the balanced cell-frequency case.

Analysis of Variance Table and F-Test

\begin{tabular}{|c|c|c|c|c|c|c|}
\hline & & & & & & $\begin{array}{l}\text { Reject } \\
\text { Equal }\end{array}$ \\
\hline $\begin{array}{l}\text { Model } \\
\text { Prob } \\
\text { Term } \\
\text { Ratio }\end{array}$ & $\begin{array}{r}\text { Means? } \\
\text { DF } \\
\text { Level }\end{array}$ & $\begin{array}{r}\text { Sum of } \\
\text { Power } \\
\text { Squares } \\
(\alpha=0.05)\end{array}$ & $\begin{array}{r}\text { Mean } \\
\text { Square } \\
(\alpha=0.05)\end{array}$ & F- & & \\
\hline $\begin{array}{l}\text { Between } \\
00000\end{array}$ & 2 & 21.46713 & 10.73356 & 23.6811 & 0.00000 & Yes 1. \\
\hline Within (Error) & $\begin{array}{l}87 \\
89\end{array}$ & 39.43309 & 0.453254 & & & \\
\hline
\end{tabular}


Welch's Test of Means Allowing for Unequal Variances

$\begin{array}{lrrrrl}\begin{array}{l}\text { Model } \\ \text { Means? }\end{array} & \text { Numerator } & \text { Denominator } & & \text { Prob } & \text { Reject Equal } \\ \text { Term } & \text { DF } & \text { DF } & \text { F-Ratio } & \text { Level } & \text { ( } \mathbf{\alpha = 0 . 0 5 )} \\ \text { Between Groups } & 2 & 39.41 & 50.9836 & 0.00000 & \text { Yes }\end{array}$

Kruskal-Wallis One-Way ANOVA on Ranks

Hypotheses

H0: All medians are equal.

$\mathrm{H} 1$ : At least two medians are different.

Test Results

Method

Not Corrected for Ties

Corrected for Ties

$\begin{array}{rrrl}\text { DF } & \begin{array}{r}\text { Chi-Squared } \\ (\mathbf{H})\end{array} & \begin{array}{r}\text { Prob } \\ \text { Level }\end{array} & \begin{array}{l}\text { Reject H0? } \\ (\mathbf{\alpha = 0 . 0 5 )}\end{array} \\ 2 & 37.7231 & 0.00000 & \text { Yes } \\ 2 & 37.7337 & 0.00000 & \text { Yes }\end{array}$

Number Sets of Ties $\quad 16$

Multiplicity Factor $\quad 204$

Group Detail

Group

control3

commercial3

probiotics3

$\begin{array}{rrr}\text { Count } & \begin{array}{r}\text { Sum of } \\ \text { Ranks }\end{array} & \begin{array}{c}\text { Mean } \\ \text { Rank }\end{array} \\ 30 & 2082.50 & 69.42 \\ 30 & 997.00 & 33.23 \\ 30 & 1015.50 & 33.85\end{array}$

Z-Value

6.1412

Median

$-3.1498$

6.485

$-2.9914$

5.645

5.415

NCSS 12.0.9

One-Way Analysis of Variance Report

Dataset Untitled

Response control3,commercial3,probiotics3

Normal Scores Tests

Hypotheses

HO: All group data distributions are the same.

$\mathrm{H} 1$ : At least one group has observations that tend to be greater than those of the other groups.

Results

Test

$\begin{array}{rrrl}\text { DF } & \begin{array}{r}\text { Chi-Squared } \\ (\mathbf{H})\end{array} & \begin{array}{r}\text { Prob } \\ \text { Level }\end{array} & \begin{array}{l}\text { Reject H0? } \\ (\mathbf{\alpha = 0 . 2 0 )}\end{array} \\ 2 & 30.8997 & 0.00000 & \text { Yes } \\ 2 & 31.3611 & 0.00000 & \text { Yes }\end{array}$




\begin{tabular}{|c|c|c|c|c|c|c|}
\hline Standard & & & & & & \\
\hline $\begin{array}{l}\text { Group } \\
\text { All } \\
\text { A: }\end{array}$ & $\begin{array}{r}\text { Count } \\
\text { (ni) } \\
90\end{array}$ & $\begin{array}{r}\text { Mean } \\
5.795556\end{array}$ & $\begin{array}{r}\text { Effect } \\
5.795556\end{array}$ & Median & $\begin{array}{l}\text { Standard } \\
\text { Deviation }\end{array}$ & $\begin{array}{r}\text { Error } \\
\sqrt{ }(\text { MSE/ni) }\end{array}$ \\
\hline control3 & 30 & 6.485333 & 0.6897778 & 6.485 & 0.07628139 & 0.1229165 \\
\hline commercial3 & 30 & 5.42 & -0.3755555 & 5.645 & 0.9547883 & 0.1229165 \\
\hline probiotics3 & 30 & 5.481333 & -0.3142222 & 5.415 & 0.6650732 & 0.1229165 \\
\hline
\end{tabular}

Plots of Means Section

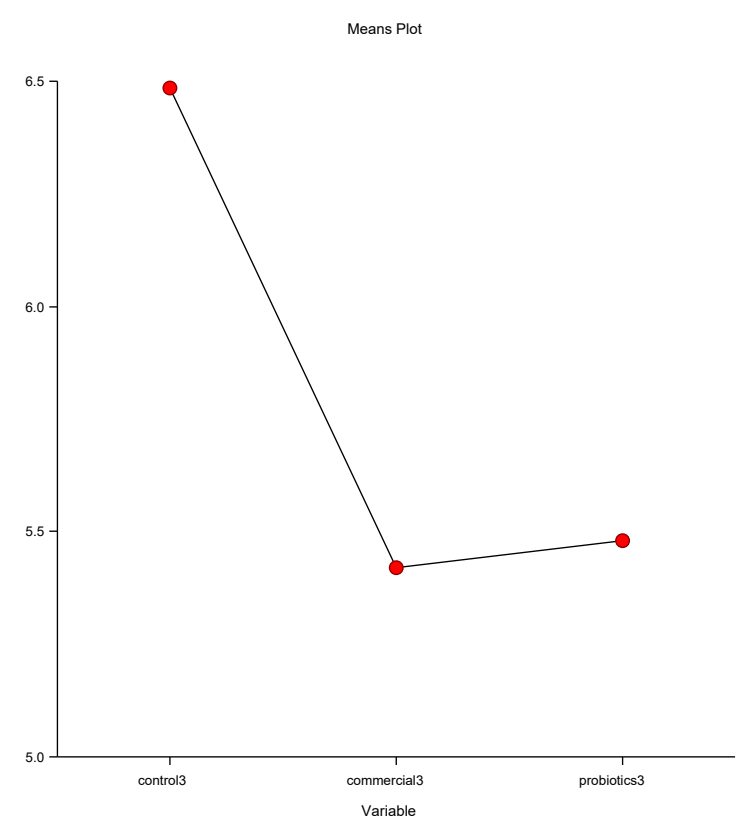

NCSS 12.0 .9

\section{One-Way Analysis of Variance Report}

Dataset Untitled

Response control3,commercial3,probiotics3

Scheffe's Multiple-Comparison Test

Response: control3,commercial3,probiotics3

Term A:

Alpha $=0.050$ Error Term $=S(A) \quad D F=87$ MSE $=0.453254$ Critical Value $=2.4905$

Different From 


$\begin{array}{llll}\text { Group } & \text { Count } & \text { Mean } & \text { Groups } \\ \text { control3 } & 30 & 6.485333 & \text { commercial3, probiotics3 } \\ \text { commercial3 } & 30 & 5.42 & \text { control3 } \\ \text { probiotics3 } & 30 & 5.481333 & \text { control3 }\end{array}$

Notes:

This report provides multiple comparison tests for all possible contrasts among the the means. These contrasts may involve more groups than just each pair, so the method is much stricter than need be. The Tukey-Kramer method provides more accurate results when only pairwise comparisons are needed.

Tukey-Kramer Multiple-Comparison Test

Response: control3,commercial3,probiotics3

Term A:

Alpha $=0.050$ Error Term $=S(A) \quad D F=87$ MSE $=0.453254$ Critical Value $=3.3796$

$\begin{array}{llll}\text { Group } & \text { Count } & \text { Mean } & \begin{array}{l}\text { Different From } \\ \text { Groups }\end{array} \\ \text { control3 } & 30 & 6.485333 & \text { commercial3, probiotics3 } \\ \text { commercial3 } & 30 & 5.42 & \text { control3 } \\ \text { probiotics3 } & 30 & 5.481333 & \text { control3 }\end{array}$

Notes:

This report provides multiple comparison tests for all pairwise differences between the means.

Kruskal-Wallis Multiple-Comparison Z-Value Test (Dunn's Test)

$\begin{array}{llll}\text { Variable } & \text { control3 } & \text { commercial3 } & \text { probiotics3 } \\ \text { control3 } & 0.0000 & 5.3649 & 5.2735 \\ \text { commercial3 } & 5.3649 & 0.0000 & 0.0914 \\ \text { probiotics3 } & 5.2735 & 0.0914 & 0.0000\end{array}$

Regular Test: Medians significantly different if $z$-value $>1.9600$

Bonferroni Test: Medians significantly different if $z$-value $>2.3940$

NCSS 12.0.9

\section{One-Way Analysis of Variance Report}

$\begin{array}{ll}\text { Dataset } & \text { Untitled } \\ \text { Response } & \text { control3,commercial3,probiotics3 }\end{array}$

Procedure Input Settings

\section{Autosaved Template File}

C:IUsers ISunghoolDocumentsINCSS 12\Procedure Templates\AutosavelOne-Way Analysis of Variance Autosaved 2019_2_17-16_9_23.t5

\section{Variables Tab}


Input Type

Response Variable(s) and a Factor (Grouping)

Variable

-- Variables

Response Variable(s)

control3, commercial3, probiotics3

Factor Variable

$<$ Empty>

-- Comparisons

Planned Comparisons

None

Reports Tab

-- Select Reports

Assumptions (Normality and Equal Variance)

Checked

Reports

EMS Report

Checked

ANOVA Report

Checked

Welch's Test

Checked

Kruskal-Wallis / Van der Waerden /

Checked

Terry-Hoeffding Tests

Means Report

Checked

.. Alpha

Test Alpha

0.05

Assumption Alpha

0.20

-- Multiple Comparison Tests

------

Bonferroni Test (All Pairs)

Bonferroni Test (Versus Control)

Dwass-Steel-Critchlow-Fligner Test

Duncan's Test

Dunnett's 2-Sided (Versus Control)

Dunnett's Lower 1-Sided (Versus Control)

Dunnett's Upper 1-Sided (Versus Control)

Dunnett's Confidence Intervals

Fisher's LSD Test

Hsu's M.C. with Best

Kruskal-Wallis Z Test (Dunn's Test)

Newman-Keuls Test

Scheffe's Test

Tukey-Kramer Test

Unchecked

Unchecked

Unchecked

Unchecked

Unchecked

Unchecked

Unchecked

Unchecked

Unchecked

Unchecked

Checked

Unchecked

Checked

Checked

Tukey-Kramer Confidence Intervals and P-Values Unchecked

.. Multiple Comparison Alpha and Decimals

MC Alpha

0.05

MC Decimals

All

One-Way Analysis of Variance Report 
$\begin{array}{ll}\text { Dataset } & \text { Untitled } \\ \text { Response } & \text { control3,commercial3,probiotics3 }\end{array}$

Procedure Input Settings (Continued)

Report Options Tab

-- Report Options ---

Variable Names

Names

Value Labels

Data Values

-- Decimal Places

------

Means and C.I. Limits

Std Deviations and Std Errors

P-Values

Test Statistics

Rank Statistics

Fractional DF

$\alpha$ in Titles

Auto (Up to 7)

Auto (Up to 7)

5

4

2

2

Plots Tab

-- Select Plots

Means Plot

Box Plot

Checked

Checked

Storage Tab

-- Data Storage Options

------

Storage Option

Do not store data 


\section{Appendix B}

NCSS 12.0.9

Repeated Measures ANOVA Report

Dataset C:IUsersISunghoolDesktopIRESEARCHIRM_report.NCSS

Response $\mathrm{pH}$

Expected Mean Squares Section

\begin{tabular}{|c|c|c|c|c|}
\hline $\begin{array}{l}\text { Source } \\
\text { Term }\end{array}$ & & $\begin{array}{l}\text { Term } \\
\text { Fixed? }\end{array}$ & $\begin{array}{l}\text { Denominator } \\
\text { Term }\end{array}$ & $\begin{array}{l}\text { Expected } \\
\text { Mean Square }\end{array}$ \\
\hline A: Groups & 2 & Yes & $B(A)$ & $S+\operatorname{cs} B+b \operatorname{cs} A$ \\
\hline$B(A)$ : sample & 24 & No & $\mathrm{S}(\mathrm{ABC})$ & $S+\operatorname{csB}$ \\
\hline C: time & 9 & Yes & $\mathrm{BC}(\mathrm{A})$ & $\mathrm{S}+\mathrm{sBC}+\mathrm{absC}$ \\
\hline$A C$ & 18 & Yes & $\mathrm{BC}(\mathrm{A})$ & $S+s B C+b s A C$ \\
\hline $\mathrm{BC}(\mathrm{A})$ & 216 & No & $\mathrm{S}(\mathrm{ABC})$ & $S+s B C$ \\
\hline$S(A B C)$ & 0 & No & & $\mathrm{S}$ \\
\hline
\end{tabular}

Note: Expected Mean Squares are for the balanced cell-frequency case.

Analysis of Variance Table

\begin{tabular}{|c|c|c|c|c|c|c|}
\hline $\begin{array}{l}\text { Source } \\
\text { Term }\end{array}$ & DF & $\begin{array}{l}\text { Sum of } \\
\text { Squares }\end{array}$ & $\begin{array}{l}\text { Mean } \\
\text { Square }\end{array}$ & F-Ratio & $\begin{array}{l}\text { Prob } \\
\text { Level }\end{array}$ & $\begin{array}{l}\text { Power } \\
(\text { Alpha }=0.05)\end{array}$ \\
\hline A: Groups & 2 & 65.80453 & 32.90226 & 2716.08 & $0.000000^{*}$ & 1.000000 \\
\hline$B(A)$ : sample & 24 & 0.2907333 & 0.01211389 & & & \\
\hline C: time & 9 & 80.10532 & 8.90059 & 2177.32 & $0.000000^{*}$ & 1.000000 \\
\hline$A C$ & 18 & 38.30251 & 2.127917 & 520.55 & $0.000000^{*}$ & 1.000000 \\
\hline $\mathrm{BC}(\mathrm{A})$ & 216 & 0.8829778 & 0.00408786 & & & \\
\hline $\mathrm{S}$ & 0 & & & & & \\
\hline Total (Adjusted) & 269 & 185.3861 & & & & \\
\hline Total & 270 & & & & & \\
\hline
\end{tabular}

Probability Levels for F-Tests with Geisser-Greenhouse Adjustments

\begin{tabular}{|c|c|c|c|c|c|c|}
\hline $\begin{array}{l}\text { Source } \\
\text { Term }\end{array}$ & DF & F-Ratio & $\begin{array}{l}\text { Regular } \\
\text { Prob } \\
\text { Level }\end{array}$ & $\begin{array}{l}\text { Lower } \\
\text { Bound } \\
\text { Epsilon } \\
\text { Prob } \\
\text { Level }\end{array}$ & $\begin{array}{l}\text { Geisser } \\
\text { Greenhouse } \\
\text { Epsilon } \\
\text { Prob } \\
\text { Level }\end{array}$ & $\begin{array}{l}\text { Huynh } \\
\text { Feldt } \\
\text { Epsilon } \\
\text { Prob } \\
\text { Level }\end{array}$ \\
\hline $\begin{array}{l}\text { A: Groups } \\
B(A) \text { : sample }\end{array}$ & $\begin{array}{r}2 \\
24\end{array}$ & 2716.08 & $0.000000^{*}$ & & & \\
\hline C: time & 9 & 2177.32 & $0.000000^{*}$ & $0.000000^{*}$ & $0.000000^{*}$ & $0.000000^{*}$ \\
\hline$A C$ & 18 & 520.55 & $0.000000^{*}$ & $0.000000^{*}$ & $0.000000^{*}$ & $0.000000^{*}$ \\
\hline $\mathrm{BC}(\mathrm{A})$ & 216 & & & & & \\
\hline S & 0 & & & & & \\
\hline
\end{tabular}

Power Values for F-Tests with Geisser-Greenhouse Adjustments Section

$\begin{array}{lll}\text { Lower } & \text { Geisser } & \text { Huynh } \\ \text { Bound } & \text { Greenhouse } & \text { Feldt }\end{array}$




$\begin{array}{lrrllll}\begin{array}{l}\text { Source } \\ \text { Term }\end{array} & \text { DF } & \text { F-Ratio } & \begin{array}{l}\text { Regular } \\ \text { Power } \\ \text { (Alpha=0.05) }\end{array} & \begin{array}{l}\text { Epsilon } \\ \text { Power } \\ \text { (Alpha=0.05) }\end{array} & \begin{array}{l}\text { Epsilon } \\ \text { Power } \\ \text { (Alpha=0.05) }\end{array} & \begin{array}{l}\text { Epsilon } \\ \text { Power } \\ \text { (Alpha=0.05) }\end{array} \\ \text { A: Groups } & 2 & 2716.08 & 1.000000 & & & \\ \text { B(A): sample } & 24 & & & & & \\ \text { C: time } & 9 & 2177.32 & 1.000000 & 1.000000 & 1.000000 & 1.000000 \\ \text { AC } & 18 & 520.55 & 1.000000 & 1.000000 & 1.000000 & 1.000000 \\ \text { BC(A) } & 216 & & & & & \\ \text { S } & 0 & & & & & \end{array}$

NCSS 12.0.9

Repeated Measures ANOVA Report

Dataset

Response

C:IUsersISunghoolDesktopIRESEARCHIRM_report.NCSS

$\mathrm{pH}$

Box's M Test for Equality of Between-Group Covariance Matrices Section

\begin{tabular}{lllllrrr}
\hline $\begin{array}{l}\text { Source } \\
\text { Term }\end{array}$ & Box's M & DF1 & DF2 & Value & $\begin{array}{r}\text { Prob } \\
\text { Level }\end{array}$ & $\begin{array}{r}\text { Chi2 } \\
\text { Value }\end{array}$ & $\begin{array}{r}\text { Prob } \\
\text { Level }\end{array} \begin{array}{r}\text { Covariance } \\
\text { Matrices } \\
\text { Equal? } \\
\text { No Test }\end{array}$
\end{tabular}

Covariance Matrix Circularity Section

\begin{tabular}{|c|c|c|c|c|c|c|c|c|}
\hline $\begin{array}{l}\text { ource } \\
\text { erm } \\
C(A)\end{array}$ & $\begin{array}{r}\text { Lower } \\
\text { Bound } \\
\text { Epsilon } \\
0.111111\end{array}$ & $\begin{array}{r}\text { Geisser } \\
\text { Greenhouse } \\
\text { Epsilon } \\
0.412505\end{array}$ & $\begin{array}{r}\text { Huynh } \\
\text { Feldt } \\
\text { Epsilon } \\
0.538038\end{array}$ & $\begin{array}{r}\text { Mauchly } \\
\text { Test } \\
\text { Statistic } \\
0.000693\end{array}$ & $\begin{array}{r}\text { Chi2 } \\
\text { Value } \\
151.3\end{array}$ & $\begin{array}{r}\text { DF } \\
44.0\end{array}$ & $\begin{array}{r}\text { Prob } \\
\text { Level } \\
0.000000\end{array}$ & $\begin{array}{r}\text { Covariance } \\
\text { Matrix } \\
\text { Circularity? } \\
\text { Violated }\end{array}$ \\
\hline
\end{tabular}

Note: Mauchly's statistic actually tests the more restrictive assumption that the pooled covariance matrix has compound symmetry.

Means and Standard Error Section

\begin{tabular}{llll}
\hline Term & Count & $\begin{array}{l}\text { Mean } \\
\text { All }\end{array}$ & $\begin{array}{l}\text { Standard } \\
\text { Error }\end{array}$ \\
A: Groups & 270 & 5.806815 & \\
commercial & & & \\
control & 90 & 5.434222 & 0.01160167 \\
probiotics & 90 & 6.504445 & 0.01160167 \\
C: time & 90 & 5.481778 & 0.01160167 \\
0 & & & \\
45 & 27 & 6.625926 & 0.01230456 \\
90 & 27 & 6.425926 & 0.01230456 \\
135 & 27 & 6.303704 & 0.01230456 \\
180 & 27 & 6.158148 & 0.01230456 \\
225 & 27 & 5.997037 & 0.01230456 \\
270 & 27 & 5.691482 & 0.01230456 \\
315 & 27 & 5.448889 & 0.01230456 \\
360 & 27 & 5.264074 & 0.01230456 \\
405 & 27 & 5.117407 & 0.01230456 \\
& 27 & 5.035555 & 0.01230456
\end{tabular}


AC: Groups,time commercial, 0 commercial,45 commercial,90 commercial,135 commercial, 180 commercial,225 commercial,270 commercial,315 commercial,360 commercial,405 control,0 control,45 control,90 control,135 control,180 control,225 control,270 NCSS 12.0.9

$\begin{array}{ll}6.616667 & 0.02131213 \\ 6.415555 & 0.02131213 \\ 6.346667 & 0.02131213 \\ 6.182222 & 0.02131213 \\ 6.004445 & 0.02131213 \\ 5.294445 & 0.02131213 \\ 4.746666 & 0.02131213 \\ 4.436666 & 0.02131213 \\ 4.196667 & 0.02131213 \\ 4.102222 & 0.02131213 \\ 6.636667 & 0.02131213 \\ 6.584445 & 0.02131213 \\ 6.54 & 0.02131213 \\ 6.506667 & 0.02131213 \\ 6.484445 & 0.02131213 \\ 6.483333 & 0.02131213 \\ 6.475555 & 0.02131213\end{array}$

\section{Repeated Measures ANOVA Report}

$\begin{array}{ll}\text { Dataset } & \mathrm{C}: \text { IUsersISunghoolDesktopIRESEARCHIRM_report.NCSS } \\ \text { Response } & \mathrm{pH}\end{array}$

\section{Means and Standard Error Section}

Term

AC: Groups,time control,315 control,360 control,405 probiotics, 0 probiotics, 45 probiotics, 90 probiotics, 135 probiotics, 180 probiotics, 225 probiotics, 270 probiotics, 315 probiotics, 360 probiotics, 405

$\begin{array}{lll}\text { Count } & \text { Mean } & \begin{array}{l}\text { Standard } \\ \text { Error }\end{array} \\ 9 & 6.46 & 0.02131213 \\ 9 & 6.446667 & 0.02131213 \\ 9 & 6.426667 & 0.02131213 \\ 9 & 6.624444 & 0.02131213 \\ 9 & 6.277778 & 0.02131213 \\ 9 & 6.024445 & 0.02131213 \\ 9 & 5.785555 & 0.02131213 \\ 9 & 5.502222 & 0.02131213 \\ 9 & 5.296667 & 0.02131213 \\ 9 & 5.124444 & 0.02131213 \\ 9 & 4.895555 & 0.02131213 \\ 9 & 4.708889 & 0.02131213 \\ 9 & 4.577778 & 0.02131213\end{array}$

\section{Plots Section}



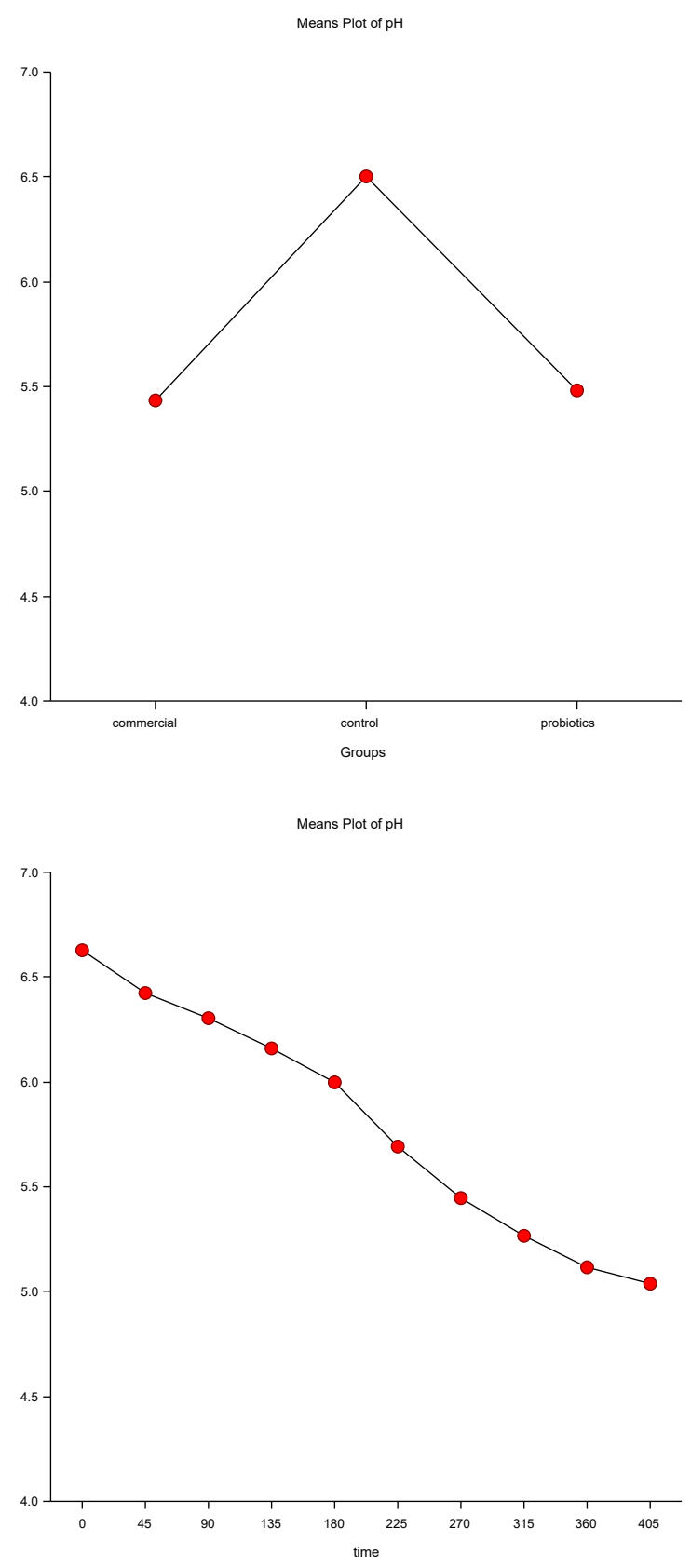

NCSS 12.0.9

\section{Repeated Measures ANOVA Report}

Dataset

Response
C:IUsersISunghoolDesktopIRESEARCHIRM_report.NCSS $\mathrm{pH}$ 

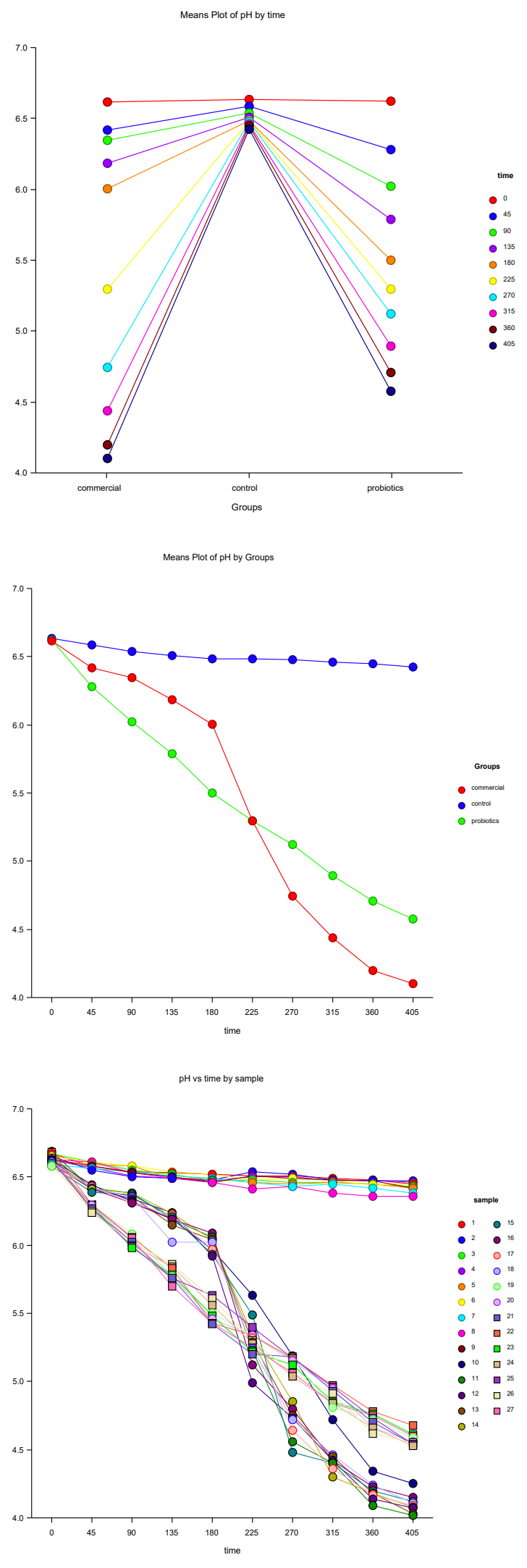


\section{Repeated Measures ANOVA Report}

$\begin{array}{ll}\text { Dataset } & \text { C:IUsersISunghoolDesktopIRESEARCHIRM_report.NCSS } \\ \text { Response } & \mathrm{pH}\end{array}$

Tukey-Kramer Multiple-Comparison Test

Response: $\mathrm{pH}$

Term A: Groups

Alpha $=0.050$ Error Term $=B(A) \quad D F=24 \quad M S E=0.01211389$ Critical Value $=3.5390$

\begin{tabular}{|c|c|c|c|}
\hline Gro & Count & Mea & $\begin{array}{l}\text { Different From } \\
\text { Groups }\end{array}$ \\
\hline rcial & 90 & 5.434222 & control, probiotics \\
\hline & 90 & 6.504445 & commercial, probiotics \\
\hline probiotics & 90 & 5.481778 & commercial, control \\
\hline
\end{tabular}

Notes:

This report provides multiple comparison tests for all pairwise differences between the means.

Planned Comparison: A: commercial vs. control

Response: $\mathrm{pH}$

Term A: Groups

Alpha $=0.050$ Error Term $=B(A) \quad D F=24 \quad M S E=0.01211389$

Comparison Value $=1.070222$ T-Value $=65.2287$ Prob $>|T|=0.000000$ Decision $(0.05)=$ Reject

Comparison Std Error $=0.01640724$ Comparison Confidence Interval $=1.036359$ to 1.104085

$\begin{array}{llll}\text { Group } & \begin{array}{l}\text { Comparison } \\ \text { Coefficient }\end{array} & \text { Count } & \text { Mean } \\ \text { commercial } & -1 & 90 & 5.434222 \\ \text { control } & 1 & 90 & 6.504445 \\ \text { probiotics } & 0 & 90 & 5.481778\end{array}$

Planned Comparison: A: commercial vs. probiotics

Response: $\mathrm{pH}$

Term A: Groups

Alpha $=0.050$ Error Term=B(A) DF=24 MSE=0.01211389

Comparison Value $=0.04755555 \quad T-$ Value $=2.8984$ Prob $>|T|=0.007889$ Decision $(0.05)=$ Reject

Comparison Std Error $=0.01640724$ Comparison Confidence Interval $=0.01369268$ to 0.08141843

Group $\quad \begin{aligned} & \text { Comparison } \\ & \text { Coefficient Count Mean }\end{aligned}$




$\begin{array}{llll}\text { commercial } & -1 & 90 & 5.434222 \\ \text { control } & 0 & 90 & 6.504445 \\ \text { probiotics } & 1 & 90 & 5.481778\end{array}$

Notes:

This section presents the planned comparison testing whether the each group is significantly different from the first group. This would be useful when the first group is a control group.

NCSS 12.0.9

\section{Repeated Measures ANOVA Report}

Dataset C:IUsersISunghoolDesktopIRESEARCHIRM_report.NCSS

Response $\quad \mathrm{pH}$

\section{Tukey-Kramer Multiple-Comparison Test}

Response: $\mathrm{pH}$

Term C: time

Alpha $=0.050$ Error Term=BC(A) DF=216 MSE $=0.00408786$ Critical Value $=4.5250$

$\begin{array}{llll}\text { Group } & \text { Count } & \begin{array}{l}\text { Mean } \\ \text { Different From } \\ \text { Groups }\end{array} \\ 45 & 27 & 6.625926 & 45,90,135,180,225,270,315,360,405 \\ 90 & 27 & 6.425926 & 0,90,135,180,225,270,315,360,405 \\ 135 & 27 & 6.303704 & 0,45,135,180,225,270,315,360,405 \\ 180 & 27 & 6.158148 & 0,45,90,180,225,270,315,360,405 \\ 225 & 27 & 5.997037 & 0,45,90,135,225,270,315,360,405 \\ 270 & 27 & 5.691482 & 0,45,90,135,180,270,315,360,405 \\ 315 & 27 & 5.448889 & 0,45,90,135,180,225,315,360,405 \\ 360 & 27 & 5.264074 & 0,45,90,135,180,225,270,360,405 \\ 405 & 27 & 5.117407 & 0,45,90,135,180,225,270,315,405 \\ & 27 & 5.035555 & 0,45,90,135,180,225,270,315,360\end{array}$

Notes:

This report provides multiple comparison tests for all pairwise differences between the means.

\section{Procedure Input Settings}

\section{Autosaved Template File}

C:IUsersISunghoolDocumentsINCSS 12/Procedure Templates\AutosavelRepeated Measures Analysis of Variance - Autosaved 2019_3_31-19_7_2.t108

Variables Tab

-- Response Variables

Response Variable(s)

$\mathrm{pH}$

-- Subject Variable

Subject Variable

sample 
-- Between Factors

\begin{tabular}{|c|c|}
\hline $\begin{array}{l}\text { Between Factor Variable } 1 \\
\text { Type } \\
\text { Comparisons } \\
\text { Between Factor Variable } 2 \\
\text { Between Factor Variable } 3\end{array}$ & $\begin{array}{l}\text { Groups } \\
\text { Fixed } \\
\text { Each witl } \\
\text { <Empty> } \\
\text { <Empty> }\end{array}$ \\
\hline -- Within Factors ------- & \\
\hline $\begin{array}{l}\text { Within Factor Variable } 1 \\
\text { Type } \\
\text { Comparisons } \\
\text { Within Factor Variable } 2 \\
\text { Within Factor Variable } 3\end{array}$ & $\begin{array}{l}\text { time } \\
\text { Fixed } \\
\text { None } \\
\text { <Empty> } \\
\text { <Empty> }\end{array}$ \\
\hline
\end{tabular}

NCSS 12.0.9

Repeated Measures ANOVA Report

Dataset C:IUsersISunghoolDesktopIRESEARCHIRM_report.NCSS

Response $\quad \mathrm{pH}$

Procedure Input Settings (Continued)

Variables Tab (Continued)

-- Model Specification

$------$

Which Model Terms

Full model. Use all terms.

Custom Model

Write model in 'Custom Model' field. Do not

$<$ Empty>

process data.

Unchecked

\begin{tabular}{|c|c|}
\hline $\begin{array}{l}\text { Reports Tab } \\
\text {-- Select Reports --- }\end{array}$ & \\
\hline $\begin{array}{l}\text { EMS Report } \\
\text { ANOVA Report } \\
\text { G G Prob Report } \\
\text { Power Report } \\
\text { Box's M Report } \\
\text { Circularity Report } \\
\text { Means Report }\end{array}$ & $\begin{array}{l}\text { Checked } \\
\text { Checked } \\
\text { Checked } \\
\text { Checked } \\
\text { Checked } \\
\text { Checked } \\
\text { Checked }\end{array}$ \\
\hline -. Alpha & \\
\hline $\begin{array}{l}\text { F-Test Alpha } \\
\text { Assumptions Alpha }\end{array}$ & $\begin{array}{l}0.05 \\
0.10\end{array}$ \\
\hline -- Multiple Comparison Tests (Fol & \\
\hline $\begin{array}{l}\text { Bonferroni Test (All Pairs) } \\
\text { Bonferroni Test (Versus Control) } \\
\text { Duncan's Test } \\
\text { Dunnett's 2-Sided (Vs Control) }\end{array}$ & $\begin{array}{l}\text { Unchecked } \\
\text { Unchecked } \\
\text { Unchecked } \\
\text { Unchecked }\end{array}$ \\
\hline
\end{tabular}




\begin{tabular}{|c|c|}
\hline Dunnett's Lower 1-Sided (Vs Control) & Unchecked \\
\hline Dunnett's Upper 1-Sided (Vs Control) & Unchecked \\
\hline Dunnett's Confidence Intervals & Unchecked \\
\hline Fisher's LSD Test & Unchecked \\
\hline Hsu's M.C. with Best & Unchecked \\
\hline Newman-Keuls Test & Unchecked \\
\hline Scheffe's Test & Unchecked \\
\hline Tukey-Kramer Test & Checked \\
\hline Tukey-Kramer Confidence Intervals and P-Values & Unchecked \\
\hline Tests for Two-Factor Interactions & Unchecked \\
\hline \multicolumn{2}{|l|}{.. MC Options } \\
\hline MC Alpha & 0.05 \\
\hline MC Decimals & All \\
\hline \multicolumn{2}{|l|}{-- Report Options --- } \\
\hline & \\
\hline Precision & Single \\
\hline Variable Names & Names \\
\hline Value Labels & Data Values \\
\hline \multicolumn{2}{|l|}{ Plots Tab } \\
\hline \multicolumn{2}{|l|}{-- Select PIC } \\
\hline Means Plot(s) & Checked \\
\hline Y-Axis Scaling & Uniform \\
\hline Subject Plot & Checked \\
\hline
\end{tabular}

